\title{
EMPLOYER PROVIDED PENSION DATA \\ IN THE NLS MATURE WOMEN'S \\ SURVEY AND IN THE HEALTH \\ AND RETIREMENT STUDY
}

\author{
Alan L. Gustman \\ Thomas L. Steinmeier \\ Working Paper 7174 \\ http://www.nber.org/papers/w7174 \\ NATIONAL BUREAU OF ECONOMIC RESEARCH \\ 1050 Massachusetts Avenue \\ Cambridge, MA 02138 \\ June 1999
}

The authors received support from the Bureau of Labor Statistics to the National Bureau of Economic Research and Dartmouth College, and from the National Institute on Aging to the National Bureau of Economic Research. All opinions expressed are those of the authors and not those of the National Bureau of Economic Research, the BLS or NIA.

(C) 1999 by Alan L. Gustman and Thomas L. Steinmeier. All rights reserved. Short sections of text, not to exceed two paragraphs, may be quoted without explicit permission provided that full credit, including (C) notice, is given to the source. 
Employer Provided Pension Data In The NLS Mature

Women's Survey And In The Health And Retirement Study

Alan L. Gustman and Thomas L. Steinmeier

NBER Working Paper No. 7174

June 1999

JEL No. D31, J14, J16, J26, J32

\begin{abstract}
We compute pension wealth from employer provided pension plan descriptions matched to respondent surveys to the National Longitudinal Survey of Mature Women (NLS-MW) and the Health and Retirement Study (HRS). These calculations provide detailed information on the level and distribution of pension wealth and a variety of incentives from pensions.

Differences between the pensions of men and women are largely explained by differences in earnings. However, there also are differences in the shapes of the pension accrual profiles of defined benefit plans that are likely to reflect the lower tenure of women.

Pension coverage is lower in the NLS-MW than in the HRS. As a result, pension wealth is lower in the NLS-MW than in the HRS. But the difference in coverage is not due to the effects of pension matching. Pension values for covered respondents are similar between the NLS-MW and HRS surveys. Systematic differences between the surveys in the rate at which pensions were matched do not have a major effect on findings as to the levels and distributions of pension wealth between the surveys.
\end{abstract}

\author{
Alan L. Gustman \\ Department of Economics \\ Dartmouth College \\ Hanover, NH 03755 \\ and NBER \\ alan.l.gustman@dartmouth.edu
}

Thomas L. Steinmeier

Department of Economics

Texas Tech University

Lubbock, Texas 79409

wbtls@ttacs.ttu.edu 
In this paper we combine detailed employer provided pension plan descriptions with survey data for nationally representative samples, to estimate the values and incentives created by the pension plans now held by the cohort that is closest to retirement. The National Longitudinal Survey of Mature Women (NLS-MW) collected employer names and addresses in 1989 and used that information to collect pension plan descriptions from employers. In 1992, the Health and Retirement Study (HRS) asked respondents for their employer's names and addresses and collected pension plan descriptions. Both surveys include populations that have recently retired, or are about to. On the basis of this examination, we determine the level of pension wealth held by these cohorts and the incentives that are shaping their retirement, and we compare pension wealth and pension wealth accruals between men and women, and between the two surveys.

These calculations are of interest for a number of reasons. Although there is a literature describing the general characteristics of pensions and the incentives they create (e.g., Kotlikoff and Wise, 1985, 1987; Gustman and Steinmeier, 1989), there is evidence that pension plans have been changing over time. Among the changes observed throughout the 1970s and 1980s, the values of pensions increased, the plan type shifted away from the defined benefit plan, and early retirement dates declined (Anderson, Gustman and Steinmeier, 1999). ${ }^{1}$ Therefore it is of interest to take stock of the situation with the latest data available.

It also is of interest to use these data to investigate the question of gender differences in pensions. Although gender differences in pensions have been investigated elsewhere, many of the

\footnotetext{
${ }^{1}$ Using panels of pensions from the 1980s and 1990s, Gustman and Steinmeier (forthcoming b) examines a panel of pension plans from the 1983 and 1989 Surveys of Consumer Finances, and finds that certain features of pension plans have changed significantly over the 1980s. Using a panel of pensions from large firms collected by theWatson Wyatt Company, they also find that pensions have changed into the 1990s.
} 
studies are dated, and as a result they miss the effects of the sharp increase in labor force activity by women, or they use more recent data, but have been have been handicapped by data limitations. $^{2}$

This study is one of only a handful of studies to investigate pension values and incentives using detailed employer provided pension plan descriptions. To estimate how pension values affect savings, or how benefits increase upon qualifying for early retirement, one requires an accurate picture of how the plan value varies with age of retirement, and that in turn requires detailed pension plan descriptions. ${ }^{3}$

Pensions are quite important, both as a source of total wealth and as a major influence on retirement behavior. On average, pensions account for about a quarter of wealth for households

${ }^{2}$ In previous studies, Gustman and Steinmeier (1986) find that, controlling for industry, occupation, and individual characteristics, women in the Survey of Consumer Finances (SCF) are 12.5 percent less likely to be covered by a pension than men. Currie (1995) finds that women are less likely to be offered pension coverage, and that the reason is their lower wages, not any special gender difference in pension coverage. Using employer provider pension data from the Survey of Consumer Finances, conditional on pension coverage, Gustman and Steinmeier (1989) find women are more likely to be covered by a defined benefit plan, and to have higher pensionearnings ratios than men.

${ }^{3}$ Some pensions plan may have a very simple structure. For example, a basic defined contribution (DC) pension may take the form of an account, such as a 401(k) plan, in which the individual's entitlement depends on the amount deposited by the employer and the employee, and on accumulated returns. However, many pensions are very complicated arrangements. Very often, a defined benefit (DB) plan pays benefits in accordance with a formula, where benefits depend nonlinearly on earnings history, time on the job, including not just tenure, but the exact dates of employment, age and tenure at retirement and/or at benefit acceptance, social security entitlement, age relative to social security retirement age, changes in CPI since retirement, and on a number of other factors. An individual who has worked long enough for the plan to be vested, but not to qualify for early retirement, may have benefits depend on one formula, while an individual who qualifies for early retirement benefits on the basis of age and service will have benefits determined by another formula. The benefits for an early retiree may change once the individual qualifies for social security. A person who qualifies for normal retirement benefits may have the benefits determined by still another formula. 
near retirement age, and more for those with higher lifetime incomes (Gustman and Steinmeier, forthcoming a). The nonlinearities in pension formulas create very sharp incentives at certain ages, and these may greatly influence retirement behavior. ${ }^{4}$

Section II describes the sample used in this paper. It discusses the methodology for creating pension wealth numbers from information in employer provided plan descriptions and respondent data, and discusses the imputation methods used when an employer record is not available. Section III presents the basic pension information from the NLS-MW and from the HRS. Comparisons are made between the findings from the two surveys, and reasons for differences in results are discussed. Gender differences in pension characteristics and plan values are analyzed. Section IV then concludes the paper.

\section{Methodology and Data Requirements for Calculating Pension Measures}

\section{Introduction:}

This paper measures pension benefits using employer provided pension plan descriptions. There are two separate sources of information. The 1992 wave of the respondent survey, for both the HRS and NLS-MW, asked respondents about pensions on current jobs and on previous jobs, and in the HRS about the periods of employment and wages on those jobs. In the NLSMW, earnings histories were collected separately from information on pension coverage.

In 1992, the HRS collected the name and address of all employers offering pensions that covered the respondent on current jobs, on the last job held if not currently employed, and on the jobs previous to the current or last job that were held at least five years. Using the name and

\footnotetext{
${ }^{4}$ Gustman, Mitchell and Steinmeier (1994) surveys the literature on pensions and the incentives they create.
} 
address supplied by the respondent in 1992, the HRS then collected the pension plan description from the firm.

In the case of the NLS-MW, pension plan descriptions were collected from employers on the basis of an address supplied by the respondent in the 1989 wave of the survey. These addresses were provided only for the employer identified by the respondent as offering their most important pension. In 1992, in addition to collecting an employment history for work on pension covered jobs, the NLS-MW also asked the names and addresses of employers if the respondent or respondent's spouse had a pension that was in pay status from a previous employer, or if either one was entitled to a pension from a previous employer that eventually would pay a benefit.

In the HRS, if an address is not obtained, or the firm does not provide a plan description, then there is no matched plan for a respondent who indicates coverage by a pension. Plan descriptions are available for only two thirds of HRS respondents who report they are covered by a pension on their current or last job, and for fewer HRS respondents covered by a pension on jobs held even earlier. As a result of the scheme adopted for data collection in the NLS-MW, there are three important ways to fail to match an employer provided plan description with the respondent provided work history. First, among the employers whose name was provided in 1989, over a third did not provide a plan description when contacted and asked to supply an SPD. Second, and this applies only to the NLS-MW data, for half the cases where a pension plan description was collected in 1989 , it is not possible to match the pension plan description with a work history from 1992. NLS staff tried to match employer names and addresses collected in the two years, but they could not make the match in half the cases where they had an employer plan description. Finally, as noted below, in a few cases where the spouse or respondent was at work 
on a pension covered job in 1992, it is not possible to match that job with the 1989 pension plan description because the indicated tenure suggests the current employment began after 1989.

When we could not make a match between the respondent and an employer provided pension plan, we imputed a pension plan record to the respondent. For each respondent without a matched pension plan, we used a pension chosen from the pool of respondents with similar characteristics who did have a plan. We used the same characteristics for the imputation procedure in each survey. Specifically, for purposes of matching, information is available on industry (13 categories), occupation (3 categories), public or private sector of work (2 categories), the wage on the job (6 categories), and whether the work is full or part-time (2 categories). ${ }^{5}$

Altogether, our procedure allows us to make a match on the basis of 936 cells. Some cells are empty. Others have more than one plan within a cell. ${ }^{6}$ When there is more than one plan description within a cell, the probability of a match with a particular observation is based on the respondents' sample weights, with the probability of a match increasing with the number of

${ }^{5}$ The NLS-MW does not provide information on hours of work on all pension covered jobs. Moreover, in the earlier panels, there is very little information about the husband's work history. However, it is possible to piece together information on hours of work, and thereby include an indicator for full-time or part-time work among the criteria for making a match. In the case of other variables, however, the data were not available on both sides of the match. As a result, we could not use indicators of unionization, firm size, or some other job characteristics as a basis for making a match. There was an analogous problem in the HRS. Firm size is not available in the HRS for previous jobs, that is for a job held before either the current job, or before the job last held by a person who was not employed in 1992.

${ }^{6}$ In the NLS-MW, there are 400 plan descriptions with the required information about the job and work history attached. 
respondents holding a particular plan. ${ }^{7}$

It is tempting to evaluate the efficacy of the matching procedure by taking only those respondents with an actual pension, and comparing that pension to the pension that would have been assigned by the matching procedure. However, that exercise will not be very informative. The reason is that with 936 cells based on matching variables, and 400 pensions, in many cases there is only one pension plan in a particular cell. In those cases, the donor pension will be the pension actually held by the respondent, and it will be matched with that same respondent, even on a random basis. The only time a respondent won't end up with his or her pension is if there is more than one pension in a cell.

There is possible concern about selection bias. To limit the extent of such bias, we have not based the imputations on a regression. Rather the technique we use selects the observations from cells with matching characteristics even if the cell is proportionately under-represented in the sample. If the cell with comparable characteristics has no pension, we expand the criteria until at least one pension is captured. Our hope is that using this technique, and basing the match on key variables, will greatly reduce the potential for selection bias. To be sure, the set of variables used to match pensions between the population with a plan description available and those without is not all inclusive. For example, because there is no information on firm size for jobs held previous to the current or last job, a measure of firm size is not available for imputing the plan description. Among those self reporting DB coverage, we do have evidence that the probability of obtaining an employer pension plan description is fifty percent greater for respondents working for larger

${ }^{7}$ For example, if 13 respondents hold a particular pension, the probability of selecting their pension for a match is 13 times higher for that plan than for a plan held by only one respondent in the sample. 
than for smaller firms, and that the difference is 2 to 1 among respondents with DC plans (Gustman, Mitchell, Samwick and Steinmeier, forthcoming a). Nevertheless, because key variables are used to match respondents without a pension plan to those with a plan, selection bias is less likely to be a problem than might first appear. By stratifying and matching on the basis of industry, occupation, sector, wages and full-time status, we are unlikely to match plan descriptions from firms that are very different from the respondent's employer. A large number of small firms did provide plan descriptions (e.g., in the HRS, 77 plans were obtained from firms with fewer than 25 employees, 176 from firms with 24 to 99 employees, and 448 plans were obtained from firms with 100 to 499 employees). So the associated cells are not likely to be empty. Using our technique, when a certain type of plan is undersampled, there is a smaller population to choose from in the selected cells, but there is little likelihood of attributing the pension from a large manufacturing firm to a respondent who works for a small firm in the service sector.

Before proceeding to examine the detailed findings, it is useful to make some aggregate comparisons with other studies. Our findings for pension wealth as a share of lifetime earnings are higher than the ratios found for 1983 using data from the Survey of Consumer Finances. In Gustman and Steinmeier (1989) we found that for those with defined benefit plans, their pensions amounted to about 14.3 percent of lifetime earnings at normal retirement age. In the present study, we find that pensions are about 4 percentage points more valuable. Pensions amount to 16.5 and 19.5 percent of lifetime earnings for males and females in the HRS respectively, and to 16.3 percent and 20.5 percent for males and females in the NLS-MW. Despite the differences in the rates at which employer provided pension plan descriptions are matched to respondent records 
in the NLS and HRS, the results are relatively close between the surveys. It is also of interest to compare the relative pension values as a share of wealth when they are computed from respondent reported data, with pensions as a share of wealth when they are computed from firm supplied plan descriptions. The HRS pension wealth computed from firm data works out to about 23 percent of total wealth. Smith (1995a, Table 13) estimated that pensions were 22 percent of total wealth in the HRS, when instead of firm reported pension amounts, pension wealth was calculated from respondent reported data. Using still another approach, Poterba, Venti and Wise (1994, Table 1) found that pensions were 20 percent of total wealth in 1994, for SIPP respondents who were 65 to $69 .^{8}$

\section{Estimating Pension Values From Employer Provided Plan Descriptions}

From Summary Plan Descriptions (SPDs), legal documents that provide detailed descriptions of all plan features, Michigan staff recorded plan features in a template that includes all of the elements of the formulas governing eligibility for benefits and benefit amounts. We use pension software developed at the University of Michigan to evaluate the plans. ${ }^{9}$ The software

${ }^{8} \mathrm{~A}$ number of surveys estimate pension values using the yearly pension received by retirees (Poterba et al., 1994). But such surveys cannot inform us about the pensions of those who are still employed. Even for those who have retired, information on the size of the pension payment obtained from a respondent may be an inaccurate indicator of the full value of the pension. For example, the pension payment may change once an individual becomes eligible for social security benefits. Moreover, pension incomes may not be received at regular intervals and constant over time. For example, income from many DC plans will result from irregular withdrawals from DC plans, or from lump sum cashouts.

${ }^{9}$ In the course of this study, we have attempted to eliminate errors in the coded plan descriptions and to perfect the pension software for more sophisticated users. For each plan description, baseline calculations were made using several hypothetical starting and ending dates for employment. We searched for pension plans that did not have a positive value after deferred vesting, which occurs at the most after 7 years for basic plans and 10 years for multiemployer 
draws on the respondent's earnings and employment history, as well as the coded plan description. ${ }^{10}$

Benefits from defined benefit plans are calculated using sections of the employer-provided defined benefit pension plan descriptions specifying normal retirement benefits, early retirement benefits, and deferred vested benefits. For those with defined contribution plans, there are sections specifying contributions and benefits accumulated. All pension data in this study,

plans, or which did not generate positive normal retirement benefits for covered workers upon meeting requirements for normal retirement. Other suspicious patterns we identified include pension accruals that jump wildly, a downward accrual before early retirement date, and anomalous differentials between early, normal and other retirement benefits. Going through these calculations has highlighted a number of pension schemes which, as coded, exhibit improperly high or low values. In the case of the HRS pension plan descriptions, The Institute for Social Research (ISR) at the University of Michigan had access to the data and the plan descriptions, and where necessary returned to the plan documents, checked the coding, and recoded plans where there were errors. This process has not been undertaken for the NLS-MW pension plan data. There was insufficient support to allow these corrections. In the cases where the plan yielded an invalid output, we imputed another plan (not simply a value). We did not make any corrections as long as the plan yielded a valid output, since we have no way of knowing what the correct plan is.

Another strategy was also followed to identify errors in the pension evaluation programs. There are two programs for evaluating pensions from employer provider data, one used in our work on pensions (e.g., Gustman and Steinmeier, 1989); the other developed at ISR. As part of the checking process, similar runs were undertaken with both programs, and outcomes compared. Not all features of the programs are identical, but this process has identified dozens of errors in both programs. This checking process was iterated a number of times until the discrepancies fell within levels that reflect differences in assumptions used rather than coding errors.

${ }^{10}$ The pension software and pension data file for use with the NLS-MW survey may be obtained from The Center for Human Resources Research (CHRR) at Ohio State University. The HRS data and public use pension software are available from the Health and Retirement Study, from Catherine Liebowitz, University of Michigan, Institute for Social Research, catlieb@isr.umich.edu. The pension software is supported by Robert Peticolas, rwp1@home.com. 
including the values of DC plans, are based on the formula provided by the firm. ${ }^{11}$ The firm is assumed to have contributed over the worker's tenure at the rate called for in the plan description. Where voluntary contributions are allowed, following the findings in Samwick and Skinner (1995), we assume they amount to 5 percent. These contributions may trigger matching contributions by the firm. ${ }^{12}$ If a person has both defined benefit and defined contribution benefits, both kinds of benefits are calculated.

What are the Advantages of Using Employer Provided Pension Plan Descriptions Instead of Descriptions of the Pensions Provided by the Respondent?

Respondents are asked for detailed descriptions of their pension plans. Why is it necessary to resort to using a description of the plan obtained from the employer?

For the cohorts we examine from the NLS-MW and from the HRS, almost four-fifths of the value of their pension wealth is in the form of defined benefit plans. It is very difficult to determine either the value of the DB plan or the sharp incentives the plan creates from self reported plan descriptions. There is a literature that explores how defined benefit plans affect the reward to retiring at different ages, as well as the reward to mobility before one reaches early retirement age. That literature concludes that there is a very sharp spike created at the early retirement age, meaning that if one stays at the firm until reaching early retirement age, and in particular works the year up to the date of qualifying for early retirement benefits, the present

${ }^{11}$ In wave 1 of the HRS, a dollar balance is reported for 70 percent of the plans (i.e., 1984 out of 2842 plans) held by respondents in their current jobs.

${ }^{12}$ Note that knowledge of the amount in the account as of 1992 is not sufficient to allow projection of the defined contribution pension. Many respondents have a number of years to go until they reach their expected retirement ages. Moreover, if the plan type is misidentified by the respondent, there will be no information in the survey indicating the amount in the account. 
value of the pension is increased sharply (Bulow, 1982, Kotlikoff and Wise, 1985 and 1987). One reason is that benefits are discounted by a smaller factor once the individual has qualified for early retirement than if he or she leaves before qualifying. Another reason is that there are special early retirement supplements. As a result, the value of the pension may decline with continued work after the early retirement age, and may decline more sharply with work after the normal retirement age.

To determine the size of these incentives, it is necessary to have the formula determining benefits for individuals who have worked long enough for their benefits to be vested, but not long enough to qualify for early retirement, the formula for benefits after having qualified for early retirement but before qualifying for normal retirement, and the formula after qualifying for normal retirement age.

Even if the respondent can accurately report the ages of qualification for early and normal retirement benefits, and the levels of benefits at the early or normal retirement age, which many respondents cannot (Gustman and Steinmeier, 1989), the respondent cannot reproduce the benefit formulas so as to allow calculation of these crucial incentives. ${ }^{13}$ The only way to determine these incentives is to obtain and code the full pension plan from the firm's Summary Plan

\footnotetext{
${ }^{13}$ Although we would expect workers to demonstrate an improved understanding of the
} options offered by their plans as they approach the age they are going to retire, it is not reasonable to expect workers to fully understand and describe all of the different features of their pensions. Many workers who are a few years or more from retirement may not fully inform themselves of the options they face. They certainly are unlikely to have thoroughly investigated the effects of their plan on workers with different amounts of experience, or with a different earnings history from their own. Also, when one spouse reports on the other's pension, as is the case with the NLS-MW, she may have an even less perfect understanding of her spouse's pension plan provisions. 


\section{Description.}

There are many other advantages to having firm reported plan descriptions. Among them, the sequence of questions asked about the pension depend on the individual's identification of the plan type. Yet respondents often misreport plan type (Mitchell, 1988; Gustman and Steinmeier, 1989). Thus a respondent with a defined benefit plan is asked an entirely different set of questions than a respondent with a defined contribution plan -- the wrong set of questions if plan type is misidentified. Many other plan details are often not reported, or are misreported. Overall, Gustman and Steinmeier (1989) find that some respondents are highly optimistic in reporting when they will qualify for early or normal retirement benefits, and that they are overly optimistic about how large their benefits will be. Accordingly, they find that the median pension values correspond relatively closely when pensions are evaluated with firm and self reported data, but the means differ substantially.

\section{The Samples}

The NLS Mature Women's Survey (NLS-MW) is a panel study of women who were 30 to 44 in 1967. The Health and Retirement Study is a panel study of households with at least one member who was between the ages of 51 and 61 in 1992. The two samples have different compositions. Most importantly, the NLS-MW does not include single males. Consequently, 36 percent of the households in the NLS-MW are single females compared to 21 percent for the HRS. The cohorts were also born in different years. In the NLS-MW, the respondent is a woman who was born from 1923 through 1937. However, the data we will use pertain not only to the respondent, but to her spouse, if married. In the HRS, the respondents are individuals who were born between 1931 and 1941. Again, their spouses may fall out of the age range. Thus the NLS- 
MW sample is older than the HRS sample, not only because the respondents were born in earlier years, but because the spouses in the NLS-MW are all men and are typically born before their wives. Also, the NLS-MW sample has been subject to 25 years of attrition, and does not include those who immigrated since 1967.

There also is a difference in the universe of pension plans that are matched to pension covered workers. The NLS-MW matched the single pension that the respondent reported as most important in 1989, whether it was from the present job or from a previous job. The HRS matched pensions from current and previous jobs, and often matched more than one pension plan per respondent.

We begin with an analysis of the pensions held by covered respondents. We then analyze the pension wealth held by households.

The sample from the NLS-MW used in this paper begins with respondents who reported in 1992 that they were covered by a pension either on a current job or on a past job. ${ }^{14}$ The corresponding sample from the HRS reports either a current job pension or a pension from a job held previously.

The HRS matched $65 \%$ of 4450 pensions in the current job in 1992, 66\% of 1390 pensions in the last job for those not employed in 1992, and 35\% of 2840 pensions from previous jobs lasting 5 years or more. In addition, the program evaluated another 750 pensions from other previous jobs having a pension. Since the survey did not ask for the employer name and address for those jobs, none of these pensions had an exact match. Averaging over all these

\footnotetext{
${ }^{14}$ The data used here are based on the response to the 1992 NLS-MW survey to make the data comparable with the HRS data.
} 
jobs yields an exact match percentage of $51 \%$. This combines a figure of almost two thirds in the current and last job pensions with a much lower figure for pensions in previous jobs, which make up a significant number of the total pensions.

For the NLS-MW, in 1992 there were about 450 wives and 300 husbands who had pensions in their current jobs. Almost all of these jobs are jobs listed in the 1989 pension section. In addition, there were 650 pensions from prior jobs listed for the wives in 1992, of which 200 can be linked back to the 1989 pension section, and there were 850 pensions from prior jobs listed for the husbands in 1992, of which 150 can be linked back to the 1989 pension section. This means that of the 1992 pensions listed either as coming from the current employer or past employers, about 50 percent could linked back to the 1989 pension section. ${ }^{15}$

In 1989, there were 1000 wives and 1200 husbands who reported on their most important pension. About 1250 of these individuals have pensions in the pension provider file, or about 57\%. Thus, of the pensions listed in the 1992 survey, about $50 \%$ of $57 \%$, or $28 \%$, have those pensions in the pension provider survey. Roughly speaking, about half of the 1992 pensions could be linked to the 1989 pension section, and half of those had pensions in the provider survey.

Table 1 in the appendix reports the number of observations by plan type, by survey, and by gender. Pension coverage in the NLS-MW is lower than in the HRS. In the NLS-MW, 56.7 percent of households report that they are covered by at least one pension, compared with 71.1 percent of households in the HRS.

As we discuss below, the differences in the compositions of the samples do not account

${ }^{15}$ Users are not allowed access to the employer name and address. However, the NLS reports variables of the form, does 89 80d match 92 114A \#1, where the question numbers indicate where the employer names are reported in each survey wave. 
for these differences in reported coverage. Some of these differences may, however, arise because the respondent is always the woman in the household, and she is asked about her husband's current or old pension, rather than asking the covered individual as in the HRS. Which data set is superior for analyzing pensions?

It is fair to ask which data set is superior for analyzing pensions. On the one hand, the pension plan data in the HRS are superior NLS-MW because the HRS is twice as likely to match a plan description with a respondent's covered earnings history. The HRS is also superior because it allows matching of other pensions beside the most important one. Nevertheless, there is important information in the plan descriptions that for many studies will make it worthwhile to use the matched pension data from the NLS-MW. It has the advantage of reporting a continuous panel over thirty years long, including a rich and complete set of information on the respondents that cannot be duplicated with a new survey such as the HRS. The HRS must obtain information on early work history either from retrospective data, or from matched administrative data that are sometimes incomplete or truncated. The advantages of the NLS-MW are not relevant for the men in the two samples, since the labor market information about the husbands on the NLS panel is incomplete and sporadically collected, and much of the information is only available on a retrospective basis in 1992. This makes the NLS-MW less useful when studying behavior in a family context. ${ }^{16}$ Also, the information provided by two surveys is sometimes complementary since the cohorts do not overlap completely. Nevertheless, for most but not all users, the pension plan data in the HRS are probably superior.

\footnotetext{
${ }^{16}$ See, however, Gustman and Steinmeier (1998), which uses pension plan descriptions in the NLS to estimate a structural model of the family retirement decision.
} 
Conceptually, the differences between the methodologies followed in the two surveys when collecting plan descriptions, and differences when matching earnings histories, could cause major differences in the pension values obtained with each survey. In fact, when comparable definitions are used, the pensions values computed from the two surveys are remarkably similar.

\section{Findings}

We report findings for respondents who are covered by a pension separately by plan type, survey and by gender of the covered individual. Because the NLS-MW only collected the most important pension, we focus the analysis on the main pension. The main pension for HRS respondents is defined here as the last pension held at or before age 50, or if there was none, the first pension started after age 50 .

Early retirement dates, plan values and other plan characteristics are the result of applying the features of the plan to the covered respondent's own reported work history. In that sense they are specific to the participant. We begin the discussion of findings with Figure 1, where we compare the early and normal retirement dates for the respondents to the two surveys. These dates depend both on plan provisions, and on the respondent's age and work history. That is, throughout this analysis, we compare the outcomes for survey respondents, rather than the outcomes produced by the pensions for a representative respondent. ${ }^{17}$

HRS Respondents Are Eligible For Early Retirement Benefits Almost A Year Earlier Than NLSMW Respondents

\footnotetext{
${ }^{17}$ In Gustman and Steinmeier (1989), we analyze outcomes for respondents to the 1983 Survey of Consumer Finances, which are conditional on the provisions of their pension plans as well as their own work history. In that paper, we also compute outcomes using the pension plans covering different respondents, but assuming a standardized work and earnings history.
} 
Early retirement age averages 55 in the NLS-MW, and eight tenths of a year earlier in the HRS. The frequency distributions of the early retirement age are shown in Figure 2. They show higher frequencies of early retirement dates for the HRS at ages 50 and 55. In the NLS-MW data 28.6 percent of respondents qualify for early retirement benefits before age 55 , and another 35.7 percent are eligible exactly at age 55 . Only 13.1 percent qualify for early retirement benefits after age 60 . In the HRS data 28.8 percent qualify for early retirement benefits before reaching the age of 55. Another 44.7 percent are eligible exactly at age 55. 5.7 percent of respondents qualify for early retirement after age 60, a smaller figure than in the NLS-MW. ${ }^{18}$ Since the NLS-MW sample is older then the HRS sample, some NLS-MW pension jobs may have begun at ages past the typical start age for HRS respondents.

Normal Retirement Age Is Almost Half A Year Later In The HRS Than In The NLS-MW.

Normal retirement age is 60.9 in the NLS-MW, and 61.3 in the HRS. Frequencies of normal retirement ages are shown in Figure 3. In the NLS-MW data, 48.6 percent are eligible for normal retirement benefits at age 65 , while 28.4 percent qualify for normal retirement benefits before the age of 60. Other spikes occur at ages 60 and 62. As seen in Figure 3, in the HRS data, 50.0 percent are eligible for normal retirement age 65, a slightly larger figure than for the NLSMW. 21.5 percent of HRS respondents qualify for normal retirement benefits before the age of 60, considerably fewer than in the NLS-MW sample.

The trends over this period were to lower early retirement ages, and to slightly higher

${ }^{18}$ Differences in gender mix resulting from the exclusion of single males from the NLSMW may account for some of the difference in results between the two surveys. However, 46.4 percent of the women in the HRS qualify for early retirement benefits exactly at age 55, while 31.9 percent of the women in the NLS-MW survey qualify for early retirement benefits at exactly age 55 . 
normal retirement ages (Anderson, Gustman and Steinmeier, 1999, and Gustman and Steinmeier, forthcoming a), corresponding to the expected effects of differences in respondent age between the surveys. The women in the NLS-MW were born between 1923 and 1937, and thus are six years older on average than the HRS population, which was born between 1931 and 1941. The age difference is greater than it might seem when spouses are included. Almost all spouses of NLS-MW respondents are men, and thus are older than the respondent. In the HRS, for any within age range respondent, roughly half the spouses are older and half are younger. Accordingly, the fact that the NLS-MW respondents are older than HRS respondents, and there has been a trend to earlier early retirement dates and later normal retirement dates, provides a second reason, beyond the difference in the dates the plan descriptions were collected, for differences between the two surveys.

Because of these differences in sample composition, it is worthwhile considering the differences in early and normal retirement ages separately for each gender in each survey. As seen in Figure 4, we again find that on average the early retirement date is earlier in the HRS than in the NLS-MW, both for women and for men. The normal retirement date is later for both men and women in the HRS.

\section{Differences in Early Retirement Ages Between the Genders Are Small}

It also is of interest to compare early and normal retirement dates between men and women in the same survey. These values are much closer between men and women within surveys than they are between respondents of the same gender in different surveys. As seen in Figure 4, women become eligible for early retirement benefits about two tenths of a year earlier in age than men in the NLS-MW, and about half a year later in age than men in the HRS. 
Different plans use different criteria to determine eligibility for early retirement. In some plans, early retirement eligibility may be determined by age as long as the respondent has attained some specified minimum service. In other plans, early retirement eligibility may be determined by more complex rules, e.g., age and service together must sum to 75 , and age must be 55 or greater. Because the odds on matching pensions were different between men and women in the NLS-MW (20.6 percent for men and 38.3 percent for women), but not in the HRS (54.5 percent for men and 56.3 percent for women), differential censoring of pension plan matches that characterize the results in the NLS-MW are not a problem in the HRS. Accordingly, we have more confidence in the finding that women become eligible for early retirement about half a year later than men, as found in the HRS. ${ }^{19}$

When comparing pension outcomes between men and women, bear in mind that women are facing different pension plans from men. For example, women are more likely to be covered by state and local government pension plans than men. As a result, eligibility for benefits need not reflect only the difference in work history between men and women.

Women Qualify for Normal Retirement Benefits at About the Same Age as Men

Women exhibit a slightly lower normal retirement age than men in the NLS-MW. The difference is three tenths of a year. In the HRS women and men exhibit the same normal retirement age.

Present Values of Defined Benefit Plans

${ }^{19} \mathrm{~A}$ half year difference in age of eligibility for early retirement benefits may nevertheless be consistent with a larger difference in overall benefits. For example, some plans allow early retirement at age 55, but require the use of a less generous benefit formula for those with 10 years service than for those with 25 years service. 
The next six figures present comparisons of the present values of benefits by survey and gender, and related information needed to assess the observed differences.

The Dollar Value of Pensions in the HRS Exceeds the Dollar Value of Pensions In The NLS-MW

Figure 5 indicates that around age 55, defined benefit pensions held by men are about 16 percent more valuable in the HRS as compared to the NLS-MW, and about 12 percent more valuable for women. For men, at older ages the differences in pension values between the surveys are proportionately about the same. For women differences between surveys are proportionately narrower at older ages. Consistent with this finding, according to Figure 6, despite the higher early retirement age in the NLS-MW, benefits at early retirement age are higher for both men and women in the HRS. The later normal retirement age in the HRS is associated with higher benefits at normal retirement, especially for men.

\section{Men's Pensions Have Much Higher Dollar Values Than Women's Pensions}

As seen in Figure 5, at any specified age of retirement, pension values are much higher for men than for women. At age 55, defined benefit pensions, discounted back to 1992, are worth about $\$ 200,000$ for men and $\$ 108,000$ for women. These are similar to the values reported at early retirement ages. At age 60 , pensions are worth about $\$ 240,000$ for men, and $\$ 140,000$ for women, again with higher values for HRS respondents. The values at normal retirement ages are about $\$ 10,000$ higher, corresponding the fact that normal retirement ages are above age 60 .

The ratio of benefits for males to females falls from about 2 to 1 at age 50 to 1.6 to 1 at age $65 .^{20}$ Bulow (1982) has shown that, for a simple defined benefit plan, two components of the

\footnotetext{
${ }^{20}$ Differences using medians are even wider than differences in means. Compare Tables
} $2 \mathrm{~A}$ and $2 \mathrm{~B}$ in the Appendix with Tables $3 \mathrm{~A}$ and $3 \mathrm{~B}$. 
rate of growth of the present value of the pension with time on the job are the growth in the final wage and the proportionate increase in tenure. If women start out with lower tenure, each year of work raises their tenure proportionately more than a year of work increases the tenure of a man who at the same age has worked longer on his job. Accordingly, we would expect to see a narrowing of the percentage differentials proceeding from early to normal retirement age. ${ }^{21}$

There are other reasons to expect the ratio of benefits paid to women vs. men to be smaller at later ages of retirement. Some pensions use a more generous benefit formula for early retirees who have longer years of service, allowing service to raise benefits in two ways, while using similar formulas to compute benefits for those qualifying at normal retirement age, whatever length of service. In such plans, the increase in benefits from service accrued between the early and normal retirement dates will be larger for women whose service does not qualify them for the most generous early retirement benefit, than for those men who are qualified for the most generous benefits. Analogous effects result when some women qualify at later ages than men for early retirement benefits. Overall the proportionate increase in benefits with age of retirement is about twice as rapid for women as it is for men.

Figure 6 shows the comparison of pension values between women and men in the different surveys at three other time periods, in 1992, at early retirement age and at normal retirement age. Again, the pensions for men substantially exceed the pensions for women. At the time of qualifying for early retirement benefits, men's benefits exceed women's by about 88 percent. At the time of qualifying for normal retirement benefits, men's benefits exceed women's benefits by

\footnotetext{
${ }^{21}$ For example, at age 55 women might have 10 years tenure vs. 20 years for men (a 2:1 ratio), but at age 65 they would have 20 years vs. 30 years for men (a 3:2 ratio).
} 
about 71 percent.

Earnings Differences Are Higher Between Men in the Two Surveys Than Between Women

Figure 7 shows cumulative earnings in the pension job. Pension differences are larger between the men in the two surveys than between the women in the two surveys because of corresponding earnings differences between the surveys, which are higher for men than women. Because the early retirement age is lower in the HRS, the earnings differences between men covered in the two surveys are muted at early retirement age. This can be seen in Figure 8 . Men Have Twice the Accumulated Earnings of Women

A major reason for the difference in benefits between men and women at each age of retirement is the difference in accumulated earnings. As seen in Figures 7 and 8, on average, men have twice the accumulated earnings of women at the indicated ages. For example, at age 60, men have cumulative earnings of around $\$ 1.5$ million, while women have cumulative earnings of around $\$ 730,000$.

\section{Benefit Earnings Ratios Are Very Similar Between the NLS-MW and the HRS}

At any given retirement age, Figure 9 indicates that the mean benefit-earnings ratios are extremely close between the surveys. Major differences are found in the 1992 values, but those disappear when the comparisons are made at the same age, or at early or normal retirement age.

\section{The Ratio of Benefits to Earnings Is Higher For Women Than for Men}

Consistent with our earlier findings based on the Survey of Consumer Finances, at any given retirement age, the ratio of mean present values of benefits to mean accumulated earnings is higher for women than for men. For example, at age 60, women's pensions are worth 19.6 percent of their cumulative earnings, while men's pensions are worth only about 16.3 percent of 
their cumulative earnings. This can be seen in Figures 9 and 10, which present the ratios of benefits to accumulated earnings. ${ }^{22}$ Higher benefit-earnings ratios for women may be influenced by their longer life expectancy. Another reason is that women begin their pension jobs at older ages. Consequently, in those plans in which qualification for retirement is based on a combination of age and tenure, women will qualify for early and normal retirement benefits with lower levels of tenure than men. Other features of pensions may also create this result; for example women would have a higher benefit to lifetime earnings ratio than men if women were more likely to be in plans that did not have a social security offset, or given their lower salaries, if they were more likely to be affected by plan minima.

\section{Defined Contribution Plans}

\section{Plans Have Higher Values for Men than for Women}

As was the case with defined benefit plans, it can be seen in Figure 11 that males covered by defined contribution plans have higher benefits that do females covered by defined contribution plans. At age 60, defined contribution plans are worth $\$ 165,000$ for men, and $\$ 73,000$ for women. As was the case with defined benefit plans, Figure 12 suggests that differences in pension benefits accord with differences in accumulated earnings. NLS-MW Respondents Exhibit Higher Ratios of DC Benefits To Earnings Than Do HRS

\section{Respondents}

As seen in Figure 13, the ratios of the present values of benefits to accumulated earnings

\footnotetext{
${ }^{22}$ There is less of tendency in the medians for women to have a higher ratio of benefits to earnings than men. Nevertheless, that still is the general tendency. Note that the figures shown in Appendix Table 3 are the ratio of the medians, not the median of the ratios. The medians of the ratios are also higher for women than for men.
} 
are higher for respondents to the NLS-MW with defined contribution plans than for HRS respondents with defined contribution plans. Caution is in order in any comparisons regarding pension amounts since we do not have direct observations on the amount of voluntary contributions. ${ }^{23}$

The Ratios of DC Benefits to Earnings Are Similar for Men and Women.

As also seen in Figure 13, the ratios of defined contribution benefits to earnings are similar for men and women. However, the ratios of benefits to earnings for those covered by DC plans are lower than the corresponding ratios for men and women covered by DB plans. Moreover, in the case of defined benefit plans, we saw in Figure 9 that the ratios of benefits to accrued earnings were much higher for women than for men. One factor leading to higher benefit ratios for women in DB plans is their higher life expectancies.

\section{Accrual Rates In Defined Benefit Plans}

Figure 14 returns the discussion to defined benefit plans. Accrual rates are shown to decline with age of retirement, as expected from the mechanics of the defined benefit formula. ${ }^{24}$ Benefit accruals are declining with age because the benefit is not increased with earnings and tenure rapidly enough to overcome the delayed receipt of benefits by those who work to later

\footnotetext{
${ }^{23}$ Note that secondary DC plans are counted together with the primary DB plan in firms offering both types, and they appear as part of the value of DB benefits.

${ }^{24}$ In this paper, pension accrual refers to the increase in the present value of the pension associated with working another year. In addition, present values of pensions are higher when they are evaluated at a later year rather than an earlier one, both because the interest rate raises the present value from one base period to the next, and because life expectancy is higher if one has survived an additional year. The pension accrual rates analyzed in this paper are purged of these two effects, and refer only to the effect on the present value of the pension of more year's work. See Gustman and Steinmeier (1989) for further discussion of the factors affecting accruals of DB pensions.
} 
ages. Like the benefits, the wage is discounted to 1992 using the interest rate, which exceeds the rate of wage growth. Accruals drop very sharply for men from peaks at $\$ 9,400$ and $\$ 11,500$ in the two surveys at age 50. The associated decline in wages with age can be seen in Figure 15. Accruals Are Greater for HRS than for NLS-MW Respondents

Comparing pension accruals for respondents to the HRS and NLS-MW, the accruals are greater for the HRS respondents. When accruals are negative, they are less negative for HRS respondents age 62 or 65 than for NLS-MW respondents. ${ }^{25}$

Pension Accruals Are Higher At Younger Ages and Lower At Older Ages for Men than Women

The peak accruals at age 50 for men are more than 50 percent larger than the $\$ 6,200$ and $\$ 7,100$ accruals that are observed for women. Pension accrual is less negative for women than men at ages 62 and 65 . Indeed, at age 65 , the accruals for men are around $-\$ 11,000$, while for women they are around $-\$ 4,000$.

The earnings data in Figure 15 show clearly that HRS male respondents have higher earnings at the indicated ages than do NLS-MW male respondents. But the women in the two surveys have very similar earnings. This may be the result both of the older age of the NLS men, and of reporting error, since the wife reports the husband's earnings in the NLS-MW, but each spouse reports own earnings in the HRS. If the wife is not fully informed about earnings, she may under report them.

Pension Accrual over Wage Accrual Is Higher in the HRS

${ }^{25}$ Today pension providers must increase yearly benefits when older workers continue at the job, whereas the common procedure in the past had been to freeze the nominal benefit for those working after the normal retirement age, so that the present value of benefits fell by the full value of the benefit for each year of work. 
Figure 16 reports the ratios at different ages of pension accrual to earnings accrual for those with defined benefit plans. From these data we see that in the HRS there is higher pension accrual over wage accrual than the NLS-MW.

Pension Accrual over Earnings Accrual Is Higher For Women than for Men

Given their lower experience, Figure 16 also indicates that the accrual rates are higher (more positive or less negative) for women than for men.

\section{Early Retirement Spikes Dominate the Pension Accrual Profile}

Examining accrual rates at ages of retirement obscures the effects of differences among plans in ages of eligibility for early and normal retirement benefits. Figures 17, 18 and 19 report the accruals for pensions, earnings and the ratios of the two by time periods before, during and after early and normal retirement ages ${ }^{26}$ Figure 17 shows the spikes in pension value in the year preceding eligibility for early and normal retirement age (labeled early retirement age in the table). ${ }^{27}$ For those in plans with an early retirement provision, the year before qualifying for early retirement benefits has the sharpest spike. For those in plans without early retirement benefits, the

\footnotetext{
${ }^{26}$ Before early retirement in the table refers to the period from the third to the first year before qualifying for early retirement. For those without early retirement benefits it refers to the third to first year before normal retirement. Early retirement age refers to the year during which the individual qualifies for early retirement benefits. Early to normal retirement is the period from the time of qualifying for early retirement to the year before qualifying for normal retirement benefits. Normal retirement age is the year during which the individual qualifies for normal retirement benefits. After normal retirement age is the three years after qualifying for normal retirement benefits.

${ }^{27}$ The benefit the respondent is eligible for depends both on the plan's provisions and on the age the respondent joined the plan. If an early retirement benefit is only available to long term employees, then respondents hired in late middle age will not show up as eligible for early retirement benefits at any age and will be counted as not being eligible for early retirement, even if the plan itself allows for early retirement for other employees with longer tenure.
} 
spike is even sharper in the year just before the individual qualifies for normal retirement benefits (labeled Normal Retirement Age in the table).

The Dollar Values of Early Retirement Spikes Are Greater In Plans Held By Men Than Women

In both surveys, the dollar value of the pension accrual spike at the age of eligibility for early retirement is greater for men than for women. On average, working the year before qualifying for early retirement benefits generates roughly an additional $\$ 60,000$ in compensation for men, and about another $\$ 36,000$ in compensation for women. As seen below, these differences in pension accrual between men and women are mainly traceable to differences in earnings.

The Differences In Measured Spikes Between the NLS-MW and HRS Differ by Gender

Among women the differences in the spikes measured by the two different surveys are sharper than the differences for men. These differences are not likely to be due to reporting error. Nevertheless, the difference in early retirement spikes between women responding to the two surveys is roughly $\$ 16,000$, while the difference in the early retirement spike for men between the surveys is only $\$ 3,000$.

The Ratio of Benefit Accrual to Earnings Accrual At Early Retirement Age Is Higher in the NLS$M W$ than in the HRS

In Figure 19, which shows the ratios of benefit accruals to earnings accruals, the prominent spike at early retirement eligibility is higher for those in the NLS-MW than for HRS respondents, by 19 percentage points for men, and by 59 percentage points for women. From Figure 19 we also see that the early retirement spike for work in the year before qualifying for early retirement is equal to one year's pay or more in each survey and for each gender. 


\section{Pension Wealth Levels in Households}

To this point we have discussed the values of pensions to covered respondents. We next turn to comparisons of pension coverage and pension wealth levels among households in the NLS-MW and in the HRS. Here it is most important to recognize the differences in the compositions of the samples. The HRS includes single males, while the NLS-MW does not. Accordingly, in Appendix Table 7 we make these comparisons among married households and among single women; when they are made between the full samples of households, caution is advised.

Pension Coverage Is Thirteen Percentage Points Higher in the HRS than NLS-MW

The share of households with a pension is about 13 percentage points higher in the HRS than in the NLS-MW. As can be seen in Appendix Table 7, there is about an 11 percentage point differential in coverage among married households, and about a 10 percentage point difference among households with single women. The remainder of the difference is due to inclusion of single men in the HRS sample, who have a ten percentage point differential over single women in coverage, and account for about one third of the single households in the HRS.

\section{Mean Pension Wealth Is Higher in HRS Households than in NLS-MW Households}

Mean pension values are higher in the HRS because pension coverage is higher. A part of the difference in coverage is due to the difference in composition of the samples, and a part of the difference may be due to reporting differences between the surveys. In the NLS-MW wives are reporting on their husband's pensions and may omit some. Pension values might also be lower in the NLS-MW due to the composition of the sample; however, among covered families, the measured values of pensions in the NLS-MW are higher than in the HRS. Specifically, among 
households with pensions, the pension value in the NLS-MW is about 2 percent higher than the pension value in the HRS. Among married households, the mean pension for households with pensions is about 3 percent higher in the NLS-MW sample. Nevertheless, given the coverage differences, among all married households, pension values are about 12 percent higher among HRS households than among NLS-MW households.

As a reflection of the age difference between the samples, a larger share of pension wealth in the HRS is due to current job rather than previous jobs.

\section{Distributions of Pensions By Household Earnings}

This section examines pension wealth outcomes for households for those in different parts of the earnings distribution. ${ }^{28}$

\section{Pension Coverage Is Higher in the HRS than NLS-MW Throughout the Earnings Distribution}

As seen from Figure 20, throughout the earnings distribution, pension coverage is higher among HRS households than among households in the NLS-MW. In the HRS, pension coverage increases with earnings through the first three fourths of the earnings distribution, and then declines slightly with earnings within the top quarter of the distribution. In the NLS-MW, after rising with earnings through the $75^{\text {th }}$ percentile, pension coverage is relatively flat within the top

\footnotetext{
${ }^{28}$ For the NLS-MW, when doing calculations for households, we calculate earnings as follows: Find the last survey with positive earnings or self-employment income. From that survey to the first survey, average the total of earnings and self-employment income (including zeros), after indexing up to 1992 wage levels. Add the amounts for the husband and wife in married households. For the HRS: Since there is only one survey, use the earnings level in the current or last job (the wage rate times the number of hours per year), and add the earnings for the husband and wife. This is only a very rough approximation to general earnings. Note that the NLS-MW earnings figures are top-coded. No adjustment is made to the top-coding. Moreover, the pension value is calculated using the top-coded amount. This will reduce the value of the pension in the NLS-MW compared to the HRS. It also may cause the difference between the pensions of men and women in the NLS-MW to be understated.
} 
quarter of the earnings distribution.

Pension Wealth Is Higher in the HRS than NLS-MW Throughout the Earnings Distribution.

In Figure 21 we see that pension wealth is higher in the HRS throughout the earnings

distribution. These differences reflect factors discussed above, including differences in household composition.

Except for the Top and Bottom Ten Percent of the Earnings Distribution, Among Pension

Covered Households, Pension Wealth Is Similar in the NLS-MW and in the HRS.

Among households that are covered by a pension, between the tenth and ninetieth percentiles, the pension values bear a similar relation to earnings within each of the surveys. The values are slightly higher in the NLS-MW pensions, but not noticeably so. For observations in the two tails, the HRS pension values are much higher relative to the wage than in the NLS-MW. These differences are due to differences in how the earnings data were collected between the two surveys. ${ }^{29}$

IV. Conclusions

${ }^{29}$ The explanations differ as to why pension-earnings ratios are much higher for the HRS in each of the two tails. For the upper income decile, the NLS-MW top-coded earnings at $\$ 100,000$, and less in earlier years. This would probably not have affected the relative rankings of households in the income distribution, but NLS-MW households in the upper decile would have had their earnings amount truncated, and with ceilings on covered benefits, their pensions truncated, but by a lesser amount. The explanation in the bottom decile has to do with the way the earnings were calculated. In the NLS, earnings are the average of non-zero earnings in all the surveys. This is meant to reflect lifetime average earnings and should average out errors over the survey years. Since we were working with only wave 1 of the HRS, this could not be done. In the HRS, earnings are earnings in either the current (Section F) or last (section G) job. As a result, the earnings measure in the HRS is measured with more noise than in the NLS-MW. Consequently, the lower decile is contaminated to a greater extent with pensions from individuals who in fact had higher average earnings in their pension jobs. 
To measure pension benefits in surveys of current workers and recent retirees, we used pension plan descriptions collected from employers by the National Longitudinal Survey of Mature Women and in the Health and Retirement Study. We compared pension outcomes between the surveys, and between men and women within each of the surveys.

\section{Similarities and Differences Between Genders}

Our results suggest that men hold pensions that are much more valuable than the pensions held by women, and that these differences are largely explained by differences in earnings. Benefit earnings ratios are actually higher for women than men, reflecting the longer life expectancy of women. There also are differences in the shapes of the pension accrual profiles of defined benefit plans. Women's pensions increase in value more rapidly than men's because women have lower tenure.

Among the specific findings on male-female differences in pensions are the following:

Early and Normal Retirement Dates: Differences in early retirement ages between women and men are small. Women qualify for normal retirement benefits at about the same age as men.

Present Values of Defined Benefit Plans: Men's pensions have much higher dollar values than women's pensions. At age 55, around average early retirement age, DB pensions are worth $\$ 200,000$ for men and $\$ 108,000$ for women. At age 60 , around average normal retirement age, DB plans are worth $\$ 240,000$ for men and $\$ 140,000$ for women. ${ }^{30}$ These differences decline with age from age 50 as women increasingly qualify for early retirement benefits. At the time of qualifying for early retirement benefits, men's benefits exceed women's benefits by about 88

${ }^{30} \mathrm{~A}$ small fraction of the measured pension differences in pension values between men and women reflect the differences in age between men and women in our samples, and the fact that when we discount to 1992, women's pensions at a fixed age are discounted over a longer period. 
percent. At the time of qualifying for normal retirement benefits, men's benefits exceed women's benefits by about 71 percent. Men have about twice the accumulated earnings of women. Thus the ratios of mean present values of benefits to mean accumulated earnings are higher for women than they are for men. For example, at age 60, women's pensions are worth about 20 percent of their cumulative earnings, while men's pensions are worth only about 16 percent of their cumulative earnings.

Present Values of Defined Contribution Plans: Defined contribution plans have higher values for men than for women. At age 60 defined contribution plans are worth $\$ 165,000$ for men and $\$ 73,000$ for women. The differences in DC pension values are due to differences in earnings between men and women, so that the ratio of benefits to cumulative earnings at age 60 is about 12 percent for both men and women. As a share of earnings, DC plans are worth less than DB plans.

Accrual Rates In Defined Benefit Plans: A leading characteristic of DB plans is the spike in the accrual rate in the year before qualifying for early retirement benefits. The pension reward for working the year before qualifying for early retirement is typically worth more than one year's pay. Accrual rates decline with age. Two important reasons are that the fraction of the population qualified for early retirement benefits increases with age, and the discounted value of the final wage declines with age as earnings growth falls short of the interest rate. Pension accruals are higher at younger ages and lower at older ages for men compared to women. Early retirement spikes are much sharper in plans held by men than by women. The peak pension accrual rates for men are at age 50 and are about twice as large as the accrual rates for women. Similarly, in the year before qualifying for early retirement benefits, pension accrual rates for men are two thirds 
again as large as the pension accrual rates for women. At age 65, pension accrual rates are around $-\$ 11,000$ for men and $-\$ 4,000$ for women. From age 55 on, the ratio of pension accrual to earnings accrual is substantially higher for women than for men, e.g., the difference is 10 percentage points at age 60 . However, there are no differences in the ratio of pension accrual to earnings accrual in the year before early retirement.

Similarities and Differences In Findings Between the NLS-MW and HRS

Pension values for covered respondents are similar between the two surveys. Pension accrual profiles differ, however. In addition, differences in pension coverage lead to higher measures of pension wealth in the HRS. Specific findings include the following:

Early and Normal Retirement Dates: HRS respondents are eligible for early retirement benefits almost a year earlier than NLS-MW respondents. Normal retirement is about half a year later in the HRS than in the NLS-MW.

Present Values of Defined Benefit Plans: At every age, benefits are lower for respondents to the NLS-MW than for respondents to the HRS. However, these benefit differences are explained by differences in earnings, so that the ratios of benefits to earnings are very close between the two surveys.

Present Values of Defined Contribution Plans: There are no systematic differences in the present values of defined contribution plans between the NLS-MW and HRS. At most ages, the ratios of benefits to earnings are within a percentage point in the two surveys.

Accrual Rates In Defined Benefit Plans: Pension accruals are greater for male HRS respondents than for male NLS-MW respondents. However, when evaluated at early retirement age, the spike is much sharper in the NLS-MW than in the HRS. HRS male respondents have 
higher earnings at each age than do NLS-MW males, but the women in the two surveys have very similar earnings. The spike in the ratio of pension accrual to earnings accrual in the year before qualifying for early retirement benefits is higher in the NLS-MW than in the HRS.

Household Differences in Pension Coverage and Pension Wealth: The share of households with a pension is about 13 percentage points higher in the HRS than in the NLS-MW, with about an 11 percentage point differential between married households in the two surveys. When the comparison is confined to married households to standardize for the composition of the sample, the mean pension for households with pensions is about 3 percent higher in the NLS-MW sample. Because of the differences in pension coverage, among all married households, pension values are higher among HRS households than among all NLS-MW households by about 12 percent.

A major difference in methodology between the surveys is that the NLS-MW collected pension plan descriptions in one wave (1989) while collecting the information required to evaluate the pensions in the next wave (1992). Also, the NLS-MW collected plan descriptions for the most important job, which is not necessarily the current or last job, and may have been held a number of years ago. And some matching is required between pension histories and earnings histories. As a result the matching rate between pensions and respondent records is half as large in the NLS-MW as in the HRS.

Among all the differences between the surveys, the most important difference is that pension coverage is lower in the NLS-MW than in the HRS. As a result, pension wealth is lower in the NLS-MW than in the HRS. But the difference in coverage is not due to the effects of pension matching. Pension values for covered respondents are similar between the NLS-MW and 
HRS surveys. Because outcomes are similar between the surveys, and there are no large, systematic differences between the surveys that are correlated with gender, this suggests that the systematic differences between the surveys in the rate at which pensions were matched do not have major effects on findings as to the levels and distributions of pension wealth between the surveys. Moreover, although the pension matching rate is lower for husbands than wives in the NLS-MW, there are no large, obvious consequences for pension wealth estimates or their distribution from the practice in the NLS-MW of obtaining work histories from the wife. 


\section{References}

Anderson, Patricia M., Alan L. Gustman and Thomas L. Steinmeier. 1999. “Trends In Male Labor Force Participation And Retirement: Some Evidence On The Role Of Pensions And Social Security In The 1970's And 1980's". Journal of Labor Economics 17(4).

Board of Trustees, Federal Old A ge and Survivors Insurance And Disability Trust

Funds, 1995 A nnual Report. U.S. Government Printing Office, 1995.

Bulow, Jeremy I. "W hat A re Corporate Pension Liabilities". Q uarterly J ournal of Economics 97 (A ugust, 1982): 435-452.

Currie, Janet. 1995. "Gender Gaps in Benefits Coverage," in The Handbook of Human Resource Management, David Lewin, Daniel M itchell and M ahmood Zaidi (ed.s), JAI Press.

Gustman, A lan L., Olivia S. M itchell, Andrew A. Samwick, and Thomas L.

Steinmeier. Forthcoming a. "Pension and Social Security W ealth In The Health A nd Retirement Study". In James Smith and Robert Willis, Editors. Wealth, Work and Health, Innovations in Measurement in the Social Sciences. A nn Arbor: University of M ichigan Press. . Forthcoming b. Evaluating Pension Entitlements". In Olivia

Mitchell, editor. Forecasting Retirement Needs and Retirement Wealth.

Gustman, Alan L., Olivia S. Mitchell and Thomas L. Steinmeier. 1994. "The Role of Pensions In The Labor Market: A Survey of the Literature". Industrial and Labor Relations Review 47(3), pp. 417-438.

1986. "Pensions and Unions". Report to the U.S. Department of Labor. . 1989. "An Analysis of Pension Benefit Formulas, Pension Wealth and Incentives From Pensions." In Ronald Ehrenberg, ed., Research In Labor Economics, Vol. 
10. Greenwich, Ct: JAI Press, pp. 33-106.

. 1998. "Retirement In Dual Career Families: Estimates Using Firm-

Reported Data”. Report to the Bureau of Labor Statistics.

. Forthcoming a. "E ffects of Pensions on Savings: A nalysis W ith

Data From The Health and R etirement Study". Carnegie-R ochester Conference Series on

Public Policy.

Forthcoming b. "Changing Pensions in Cross-Section and Panel Data:

Analysis with Employer Provided Plan Descriptions". In Proceedings, National Tax Association.

Kotlikoff, Laurence J. and David A. Wise. 1985. "Labor Compensation and the Structure of Private Pension Plans: Evidence for Contractual vs. Spot Labor Markets”. In David A. Wise, editor, Pensions, Labor and Individual Choice. Chicago: University of Chicago Press, pp. 55-85. 1987. “The Incentive Effects of Private Pension Plans. In Zvi Bodie,

John B. Shoven and David A. Wise editors, Issues in Pension Economics. Chicago, University of Chicago Press, pp. 283-336.

Mitchell, Olivia. 1988. "Worker Knowledge of Pension Provisions." Journal of Labor

Economics 6(1): 28-39.

Poterba, James M., Steven F. Venti and David A. Wise. 1994. “Targeted Retirement Saving and the Net Worth of Elderly Americans. American Economic Review, Papers and Proceedings 84: 180-85.

Smith, James P. 1995. "Racial and Ethnic Differences in W ealth U sing The HRS". J ournal of Human Resources 30 (Supplement): S158-S183. 
Samwick, A ndrew A. and J onathan Skinner. 1995. "H ow W ill D efined Contribution Pension Plans A ffect Retirement Income?". Hanover, N ew Hampshire. 
</ref_section> 
Figure 1: Average Early and Normal Retirement Ages in Defined Benefit Plans in the NLS-MW and HRS

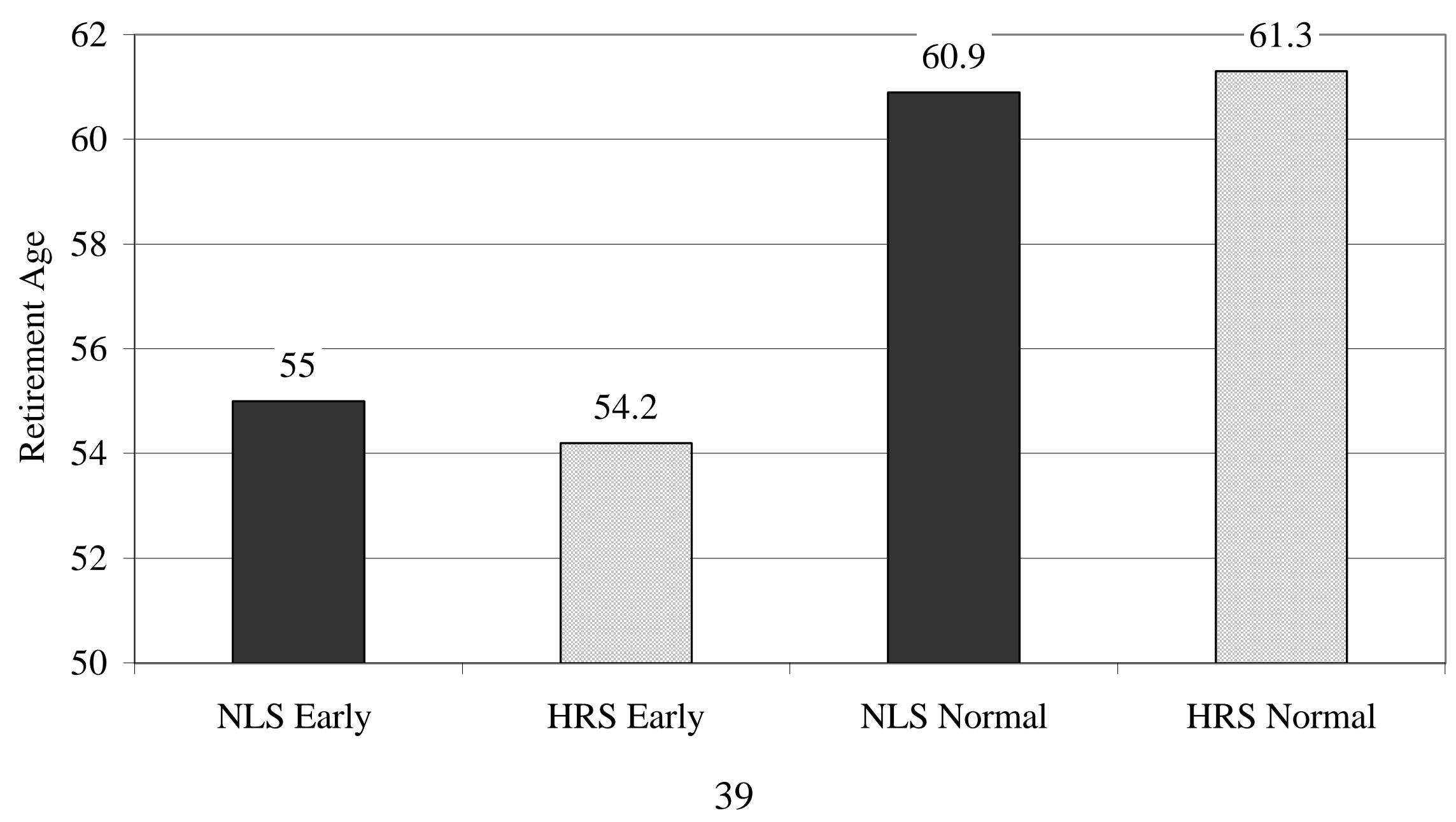


Figure 2: Frequencies of Early Retirement Ages in Defined Benefit Plans in the NLS-MW and HRS

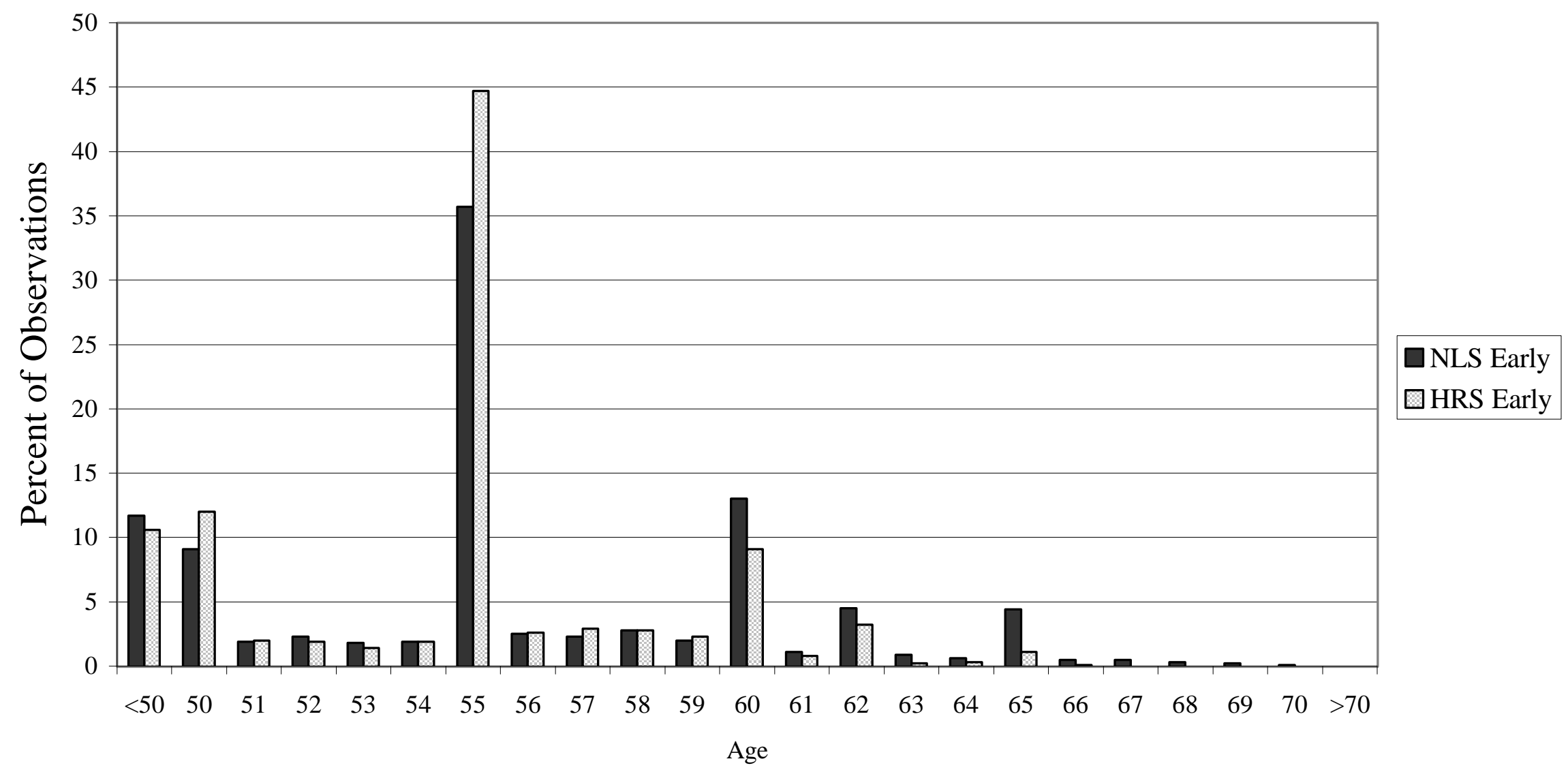


Figure 3: Frequencies of Normal Retirement Ages in

Defined Benefit Plans in the NLS-MW and HRS

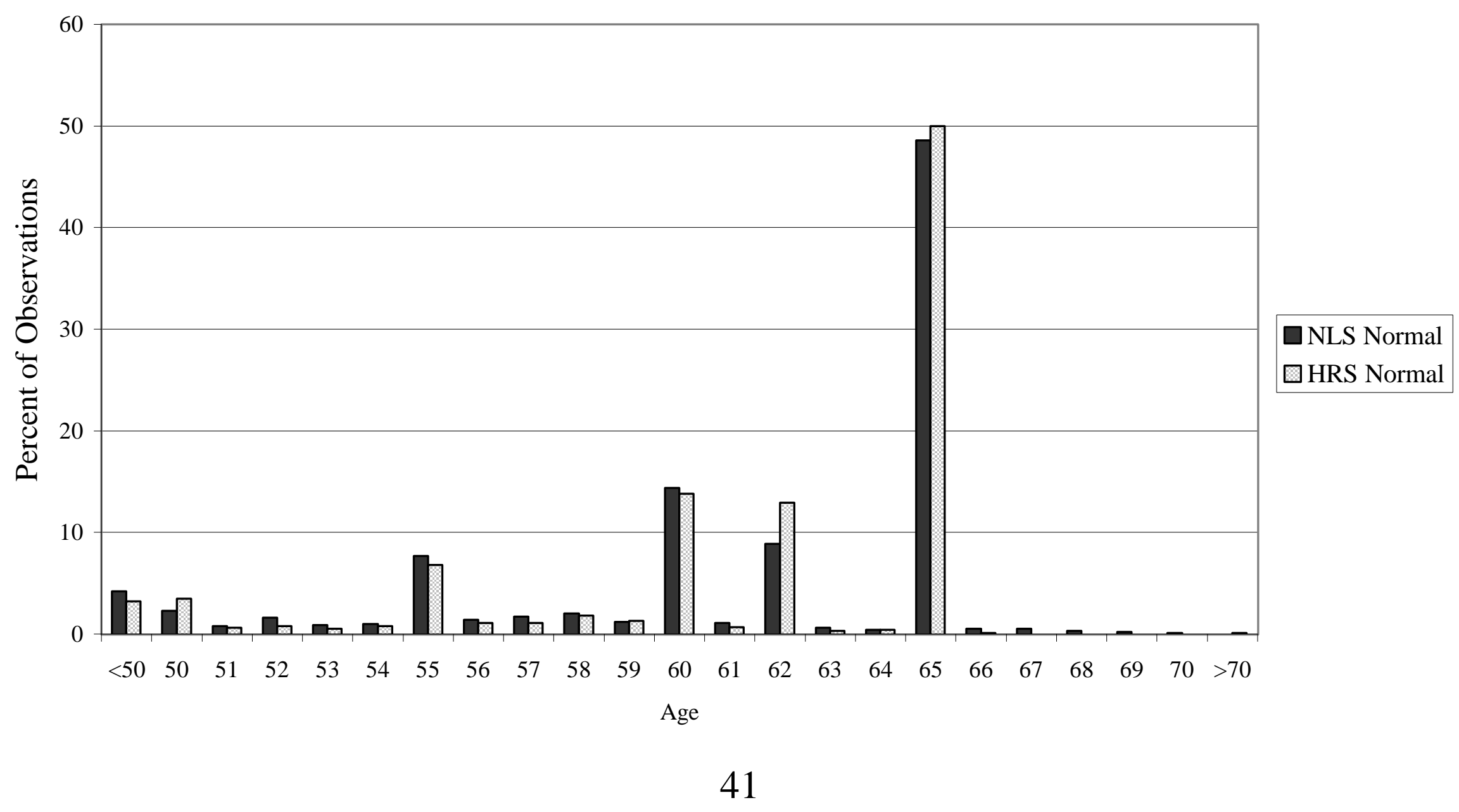


Figure 4: Frequencies of Early and Normal Retirement Ages in

Defined Benefit Plans By Survey and Gender

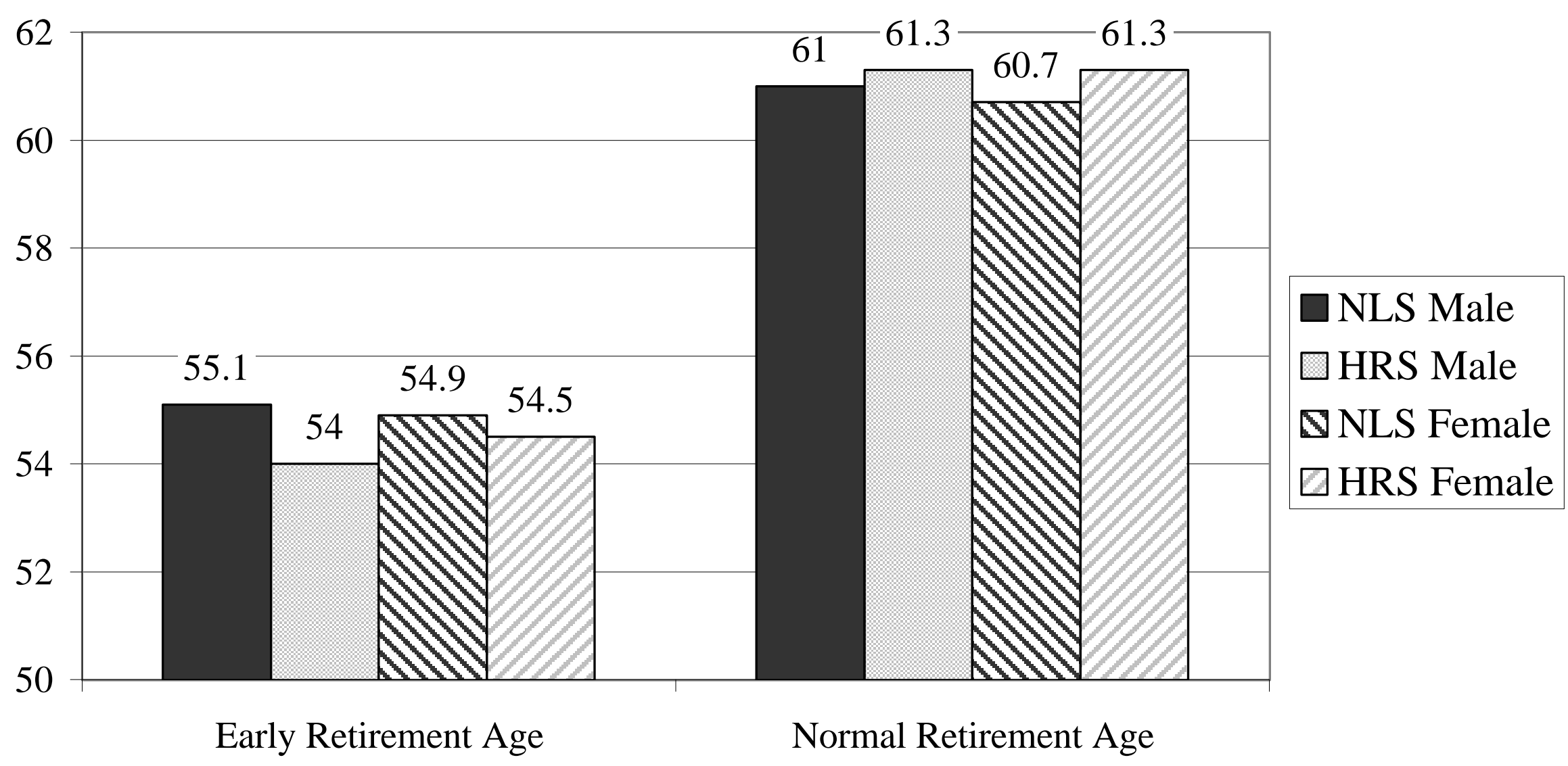


Figure 5: Present Values of Defined Benefit Pensions by Survey, Gender and Retirement Age

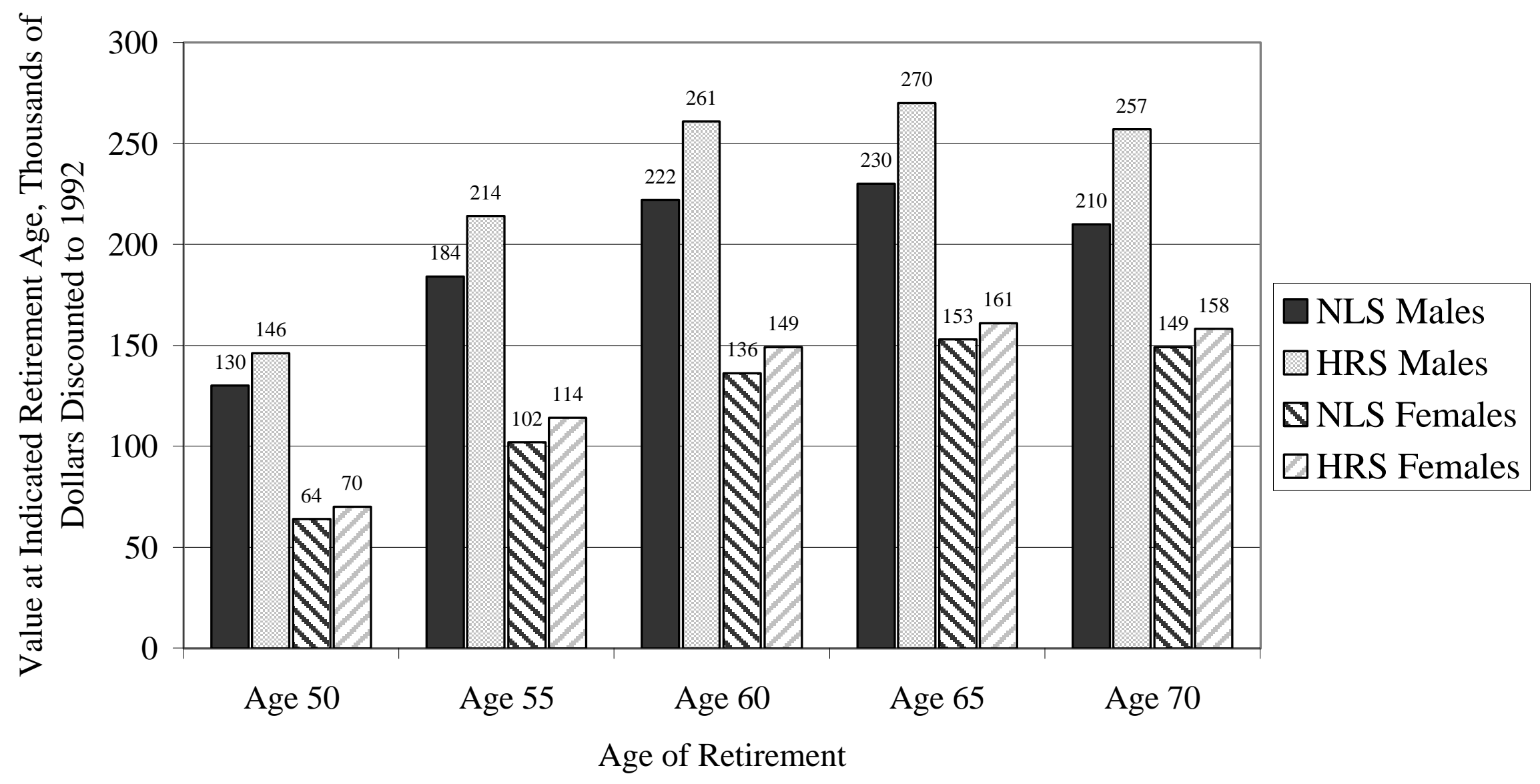




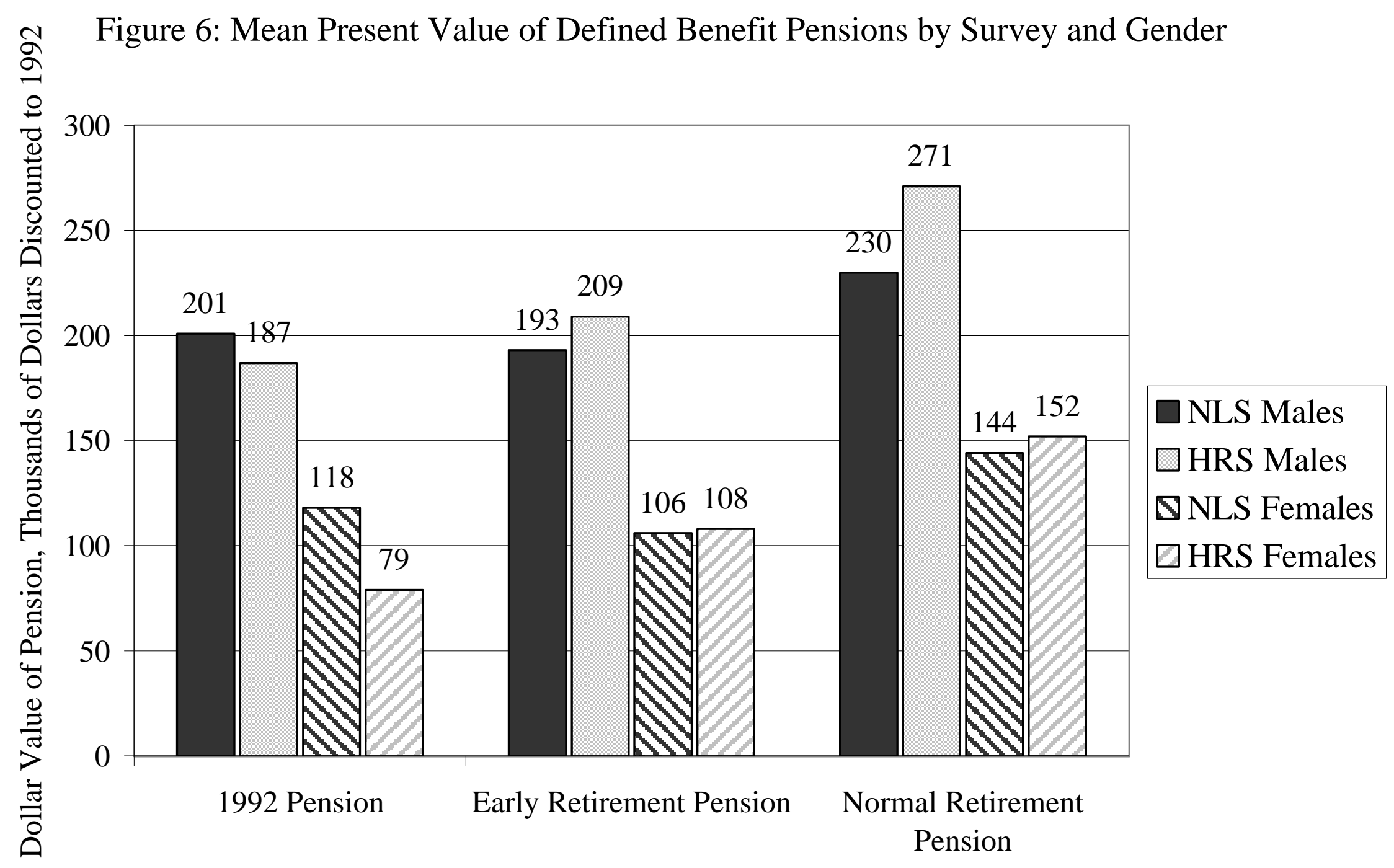


Figure 7: Cumulative Value of Earnings for those with Defined Benefit Pensions by Survey, Gender and Retirement Age

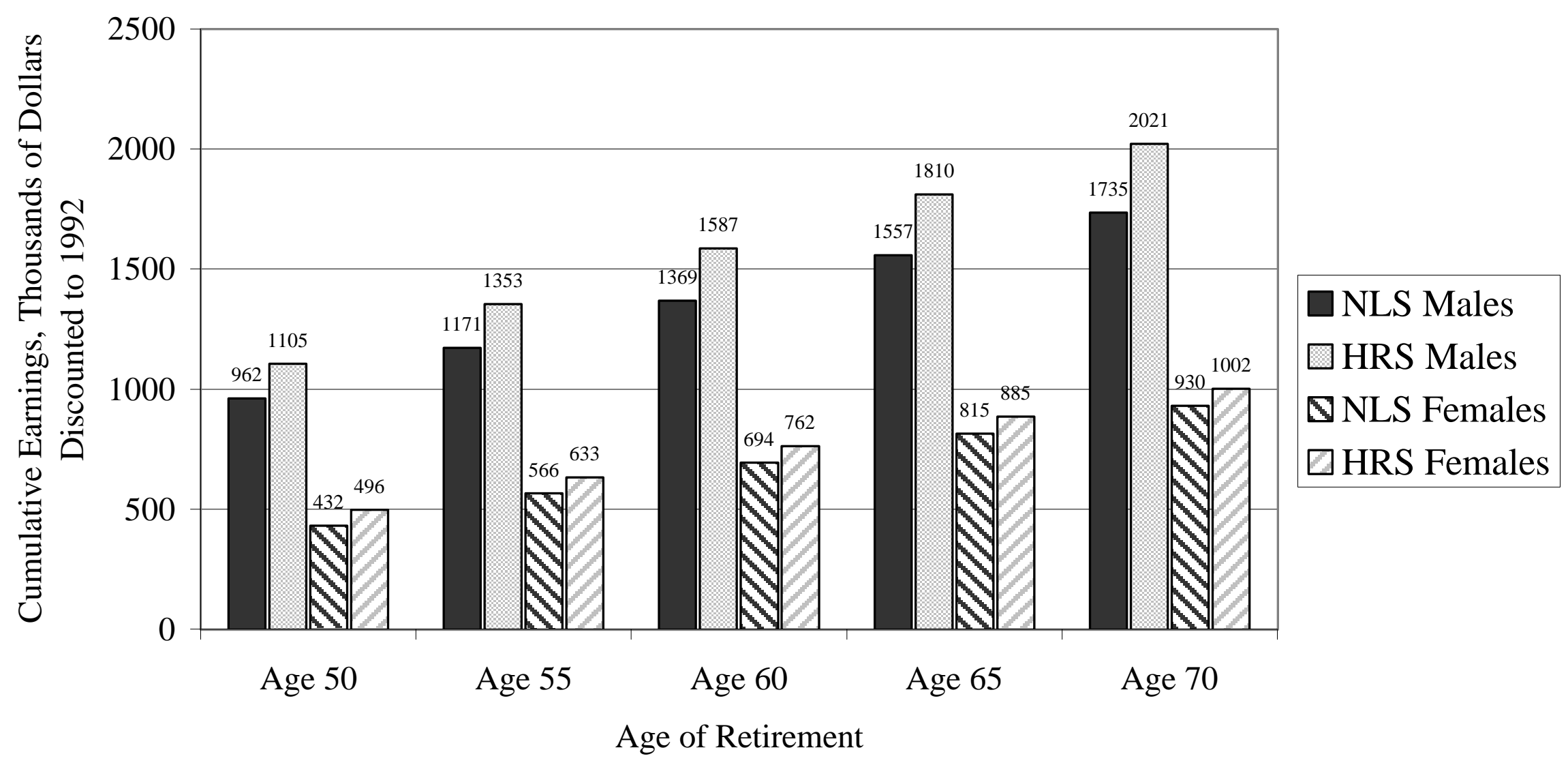


Figure 8: Cumulative Earnings for those with Defined Benefit Plans by Survey and Gender, at Alternative Retirement Dates

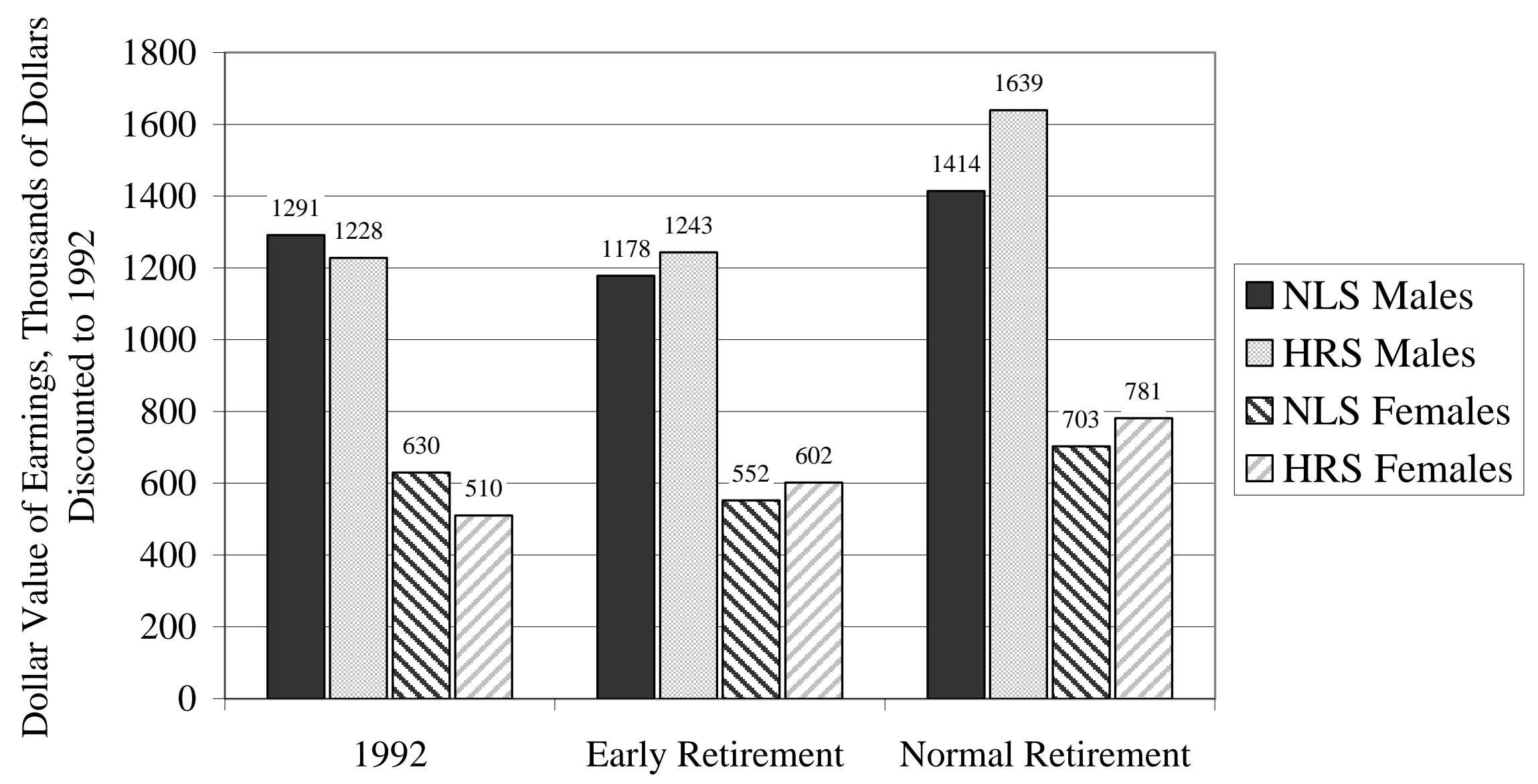


Figure 9: Present Value of Pension over Accumulated Earnings for those with Defined Benefit Plans by Survey, Gender and Retirement Age

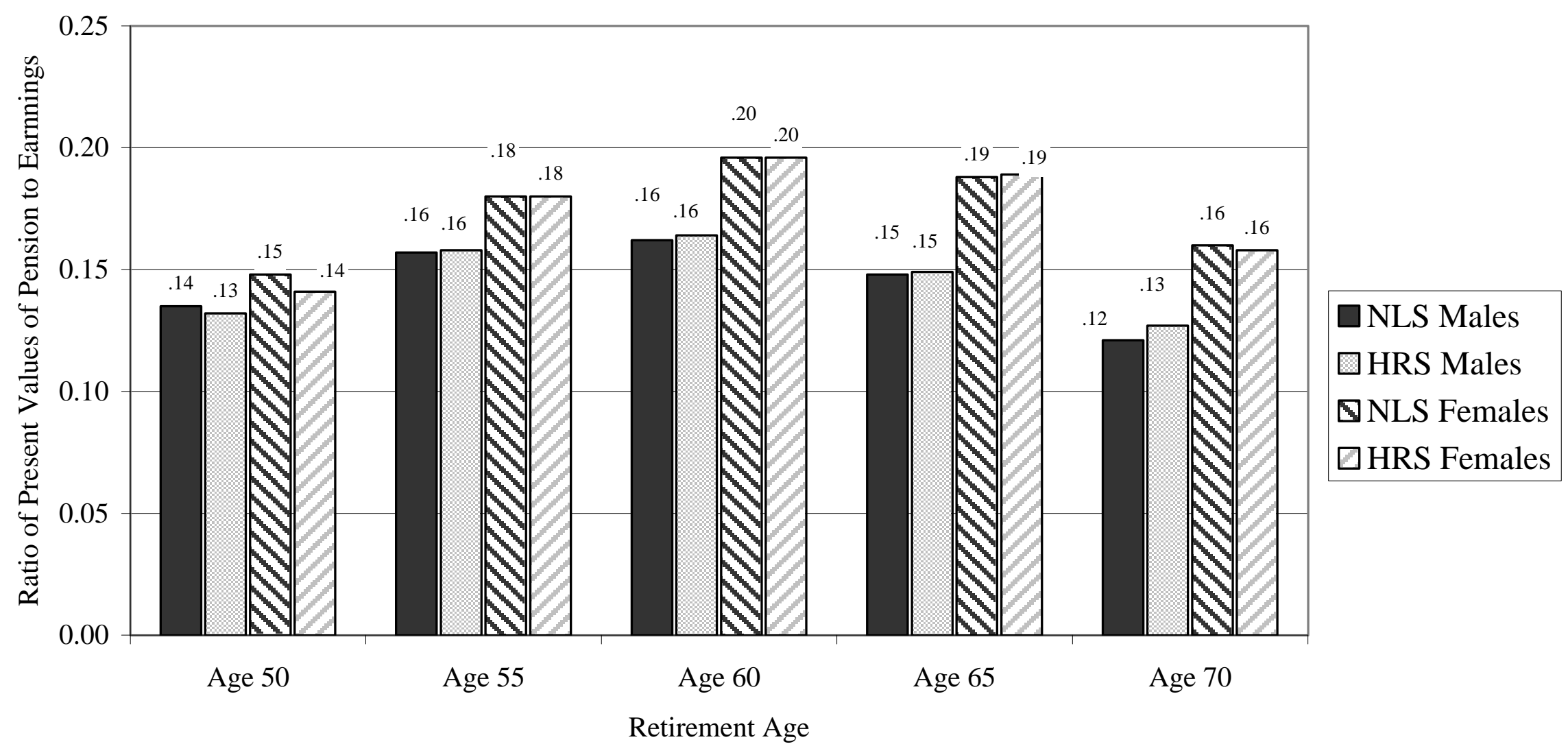


Figure 10: Present Value of Pension over Accumulated Earnings for those with Defined Benefit Plans by Survey, Gender and Retirement Age

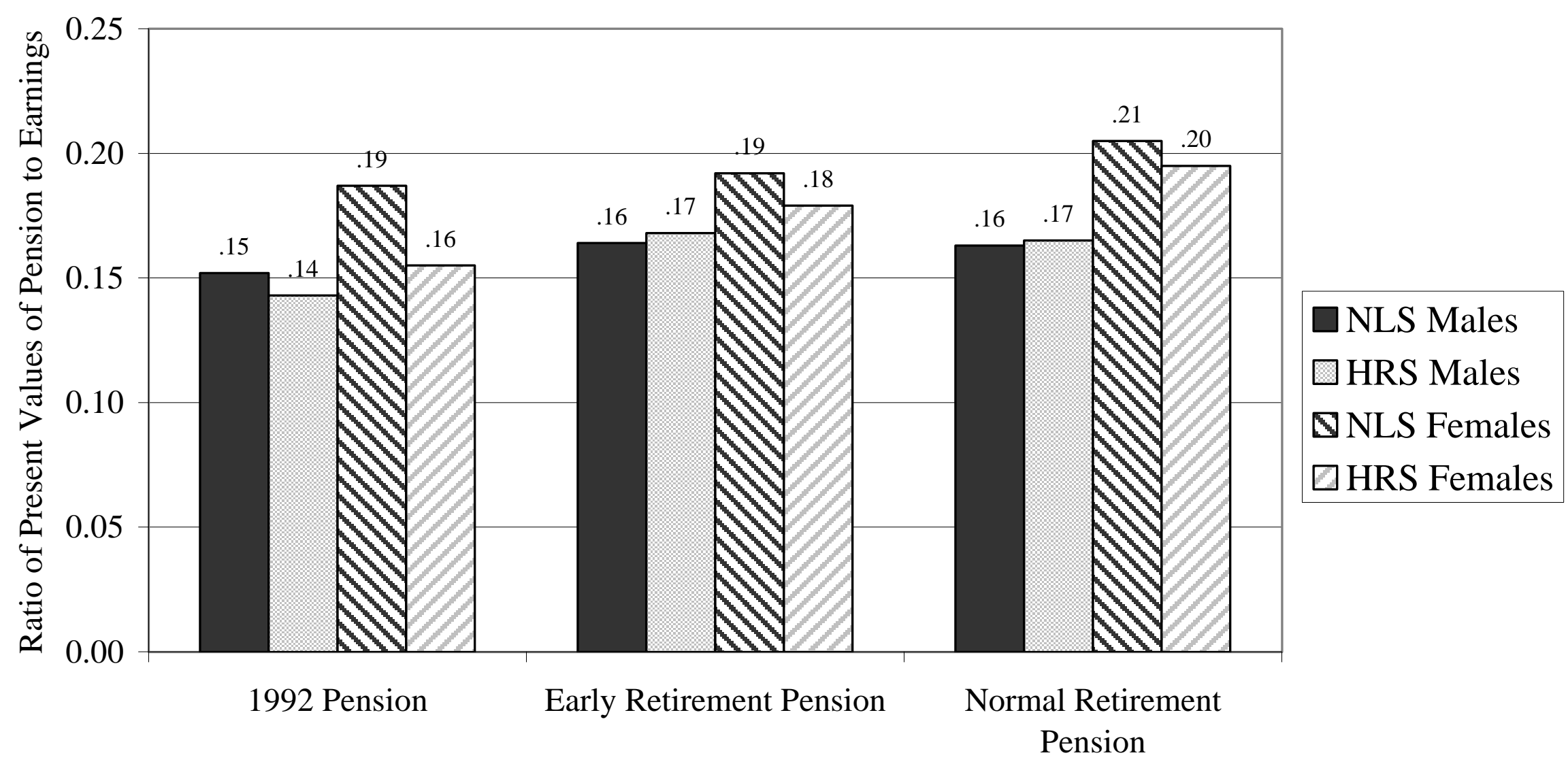


Figure 11: Present Values of Defined Contribution Pensions by Survey, Gender and Retirement Age

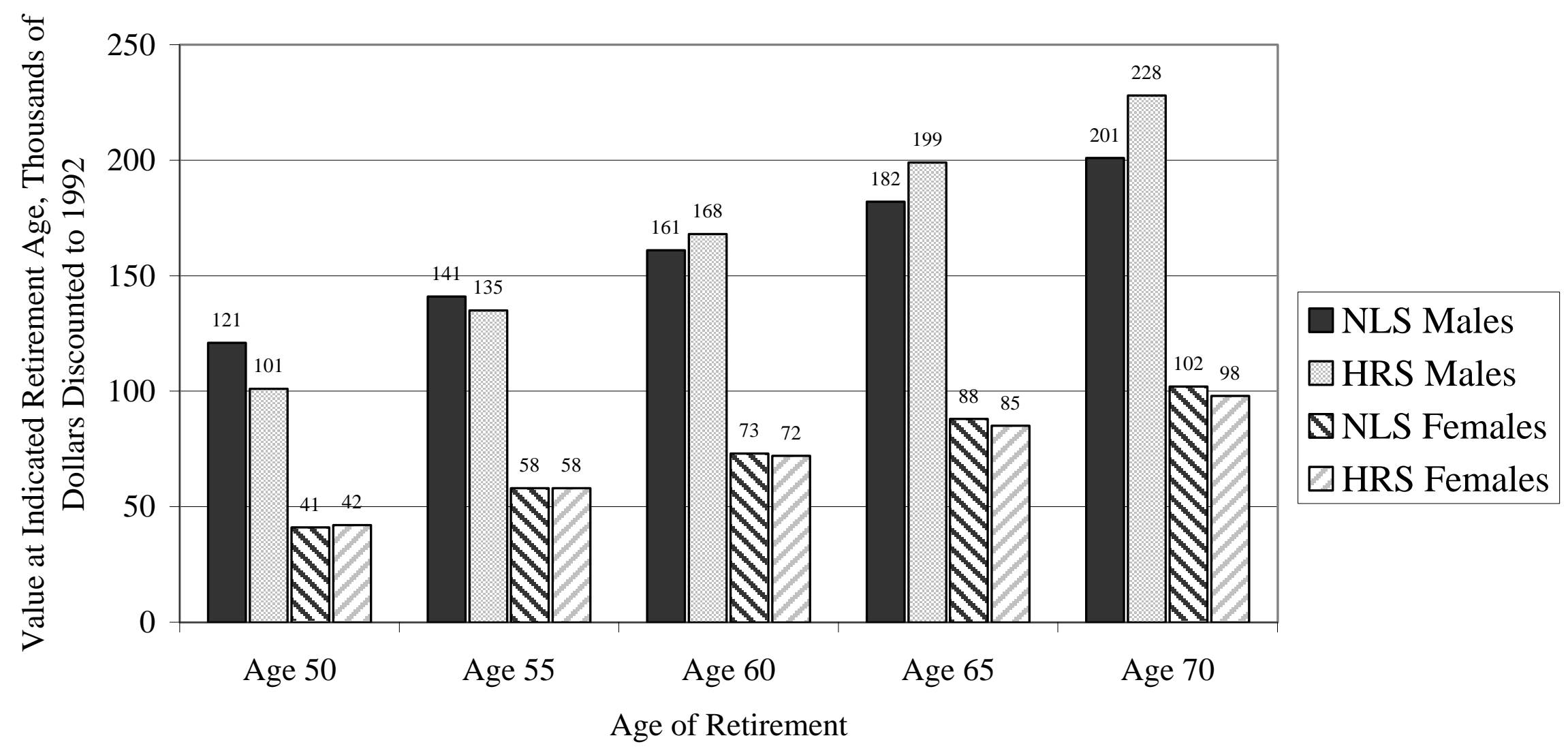


Figure 12: Cumulative Value of Earnings for those with a Defined Contribution Plan by Survey, Gender and Retirement Age

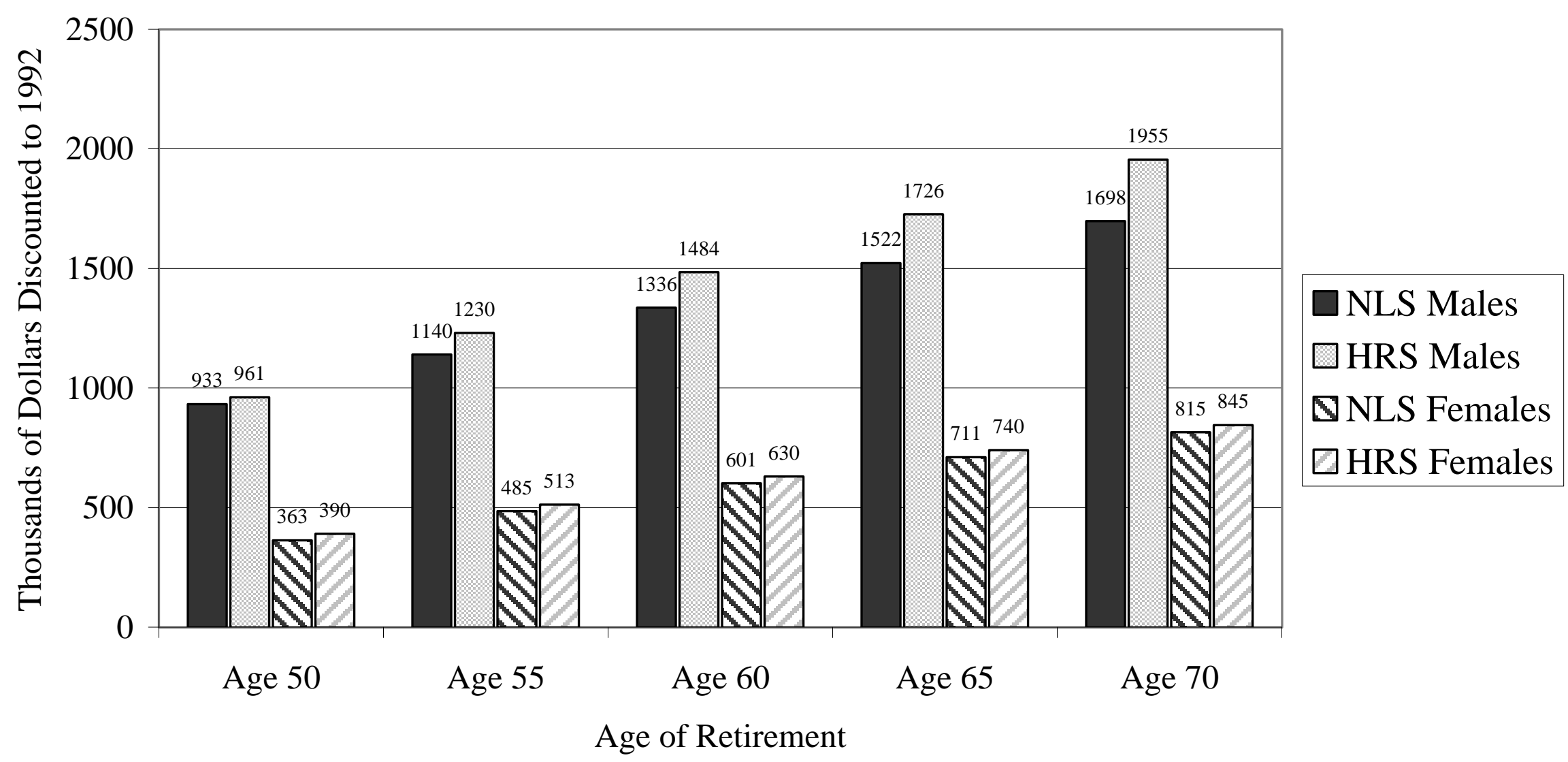


Figure 13: Present Value of Defined Contribution Pension over Accumulated Earnings by Survey, Gender and Retirement Age

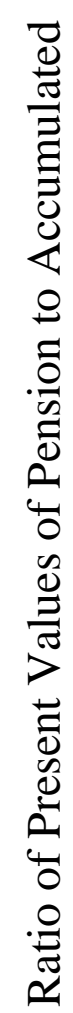

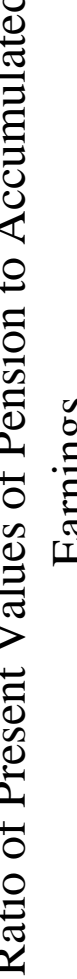

0.14

.13

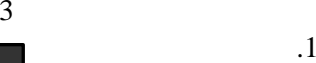

0.12

0.10
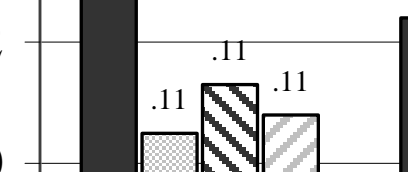

12

.12

.12

.12

$12 \quad .12$
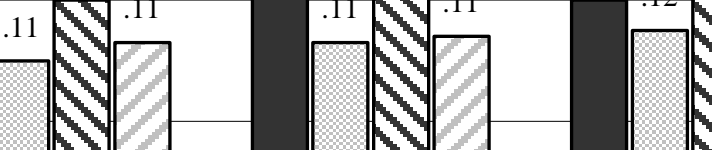

$.12 \quad .12 \quad .12$

$\underset{0}{.} 0.08$

焉 0.06

0.04

0.02

0.00

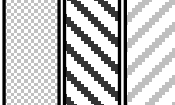

Age 50

$\square$ NLS Males

$\square$ HRS Males

$\triangle$ NLS Females

$\square$ HRS Females

Retirement Age 


\section{Figure 14: Defined Benefit Pension Accrual By Survey, Gender and Age}

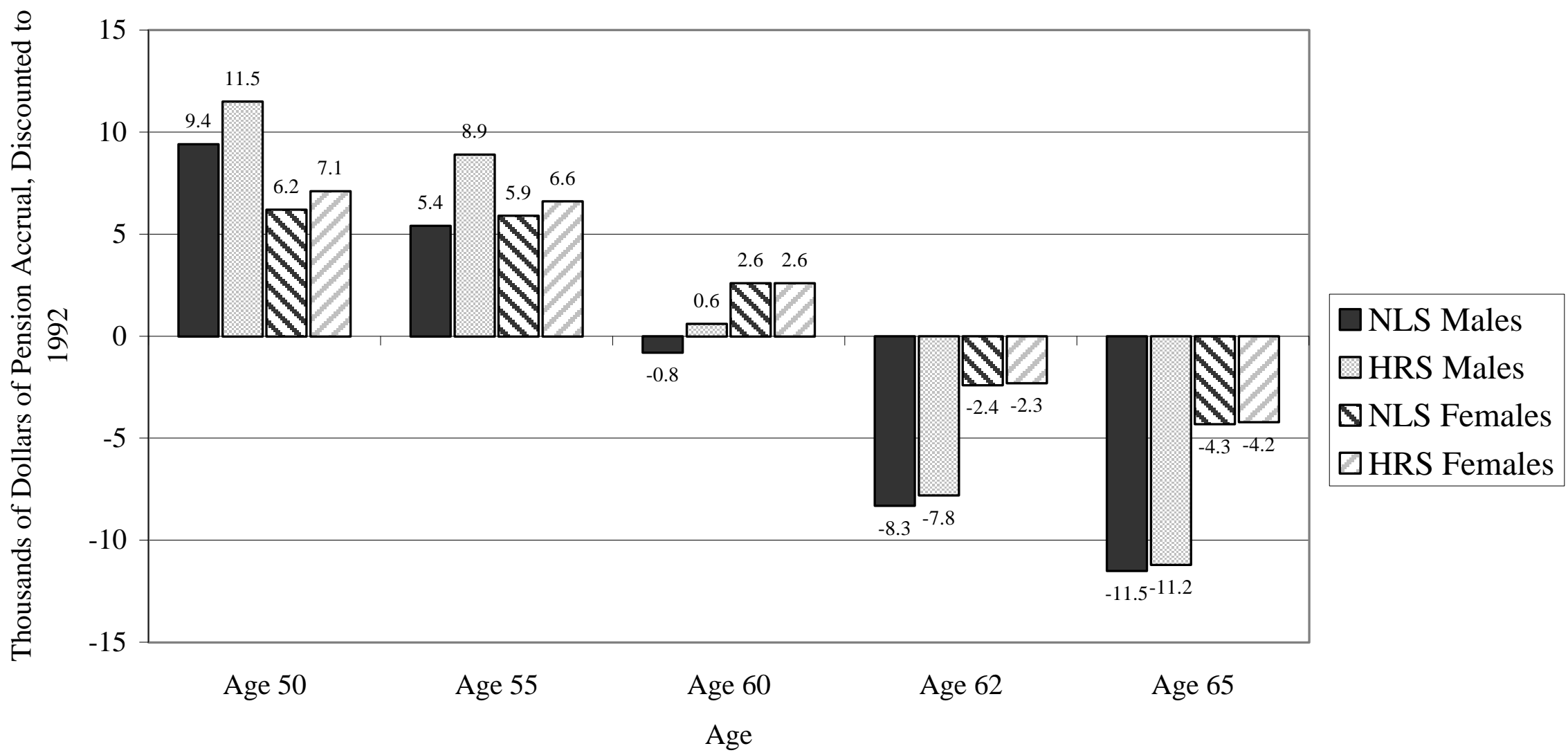


Figure 15: Earnings Accrual for those with DB Plans by Survey, Gender and Age

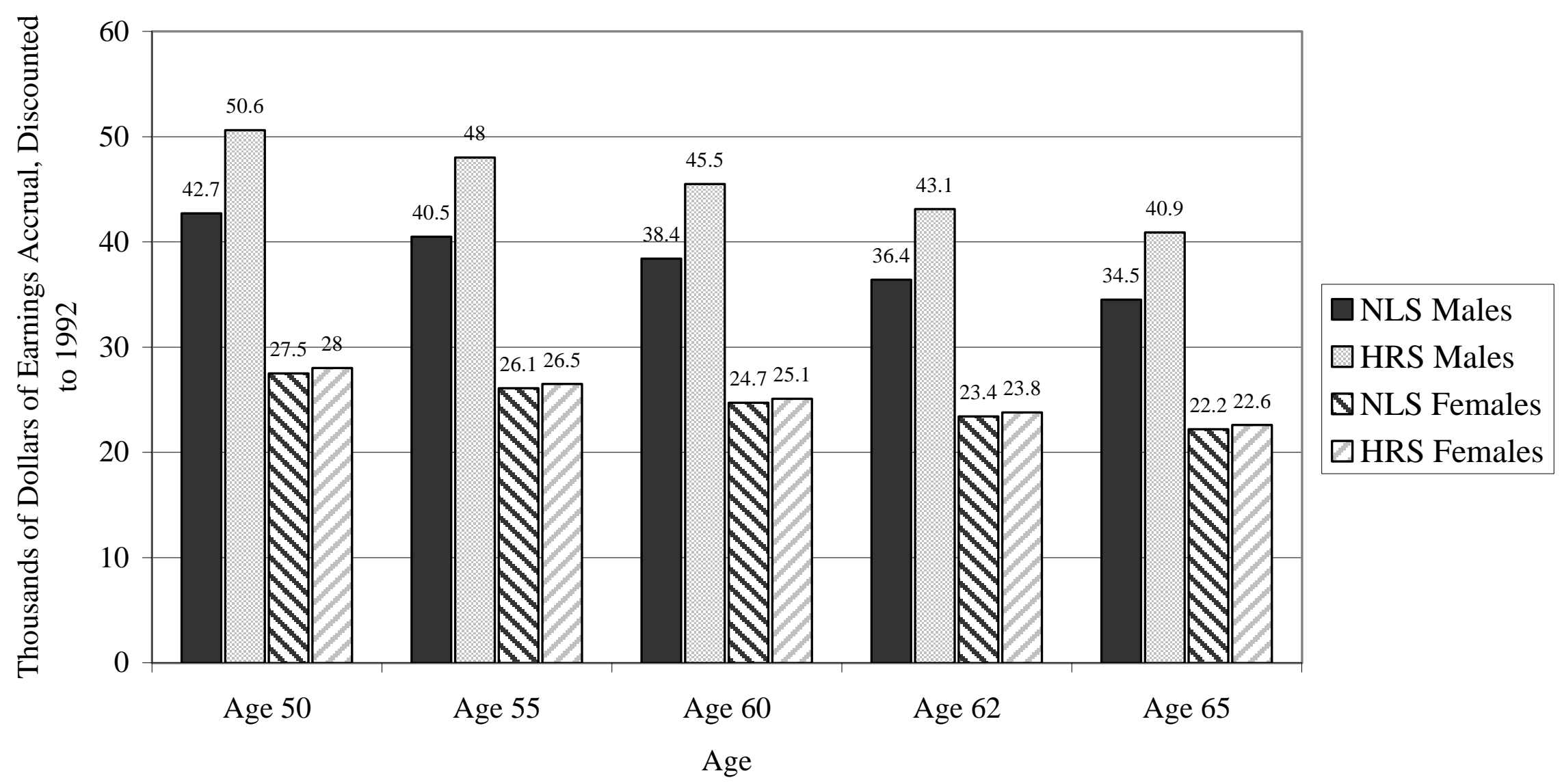


Figure 16: Ratio of Pension Accrual to Earnings Accrual for those with Defined Benefit Plans

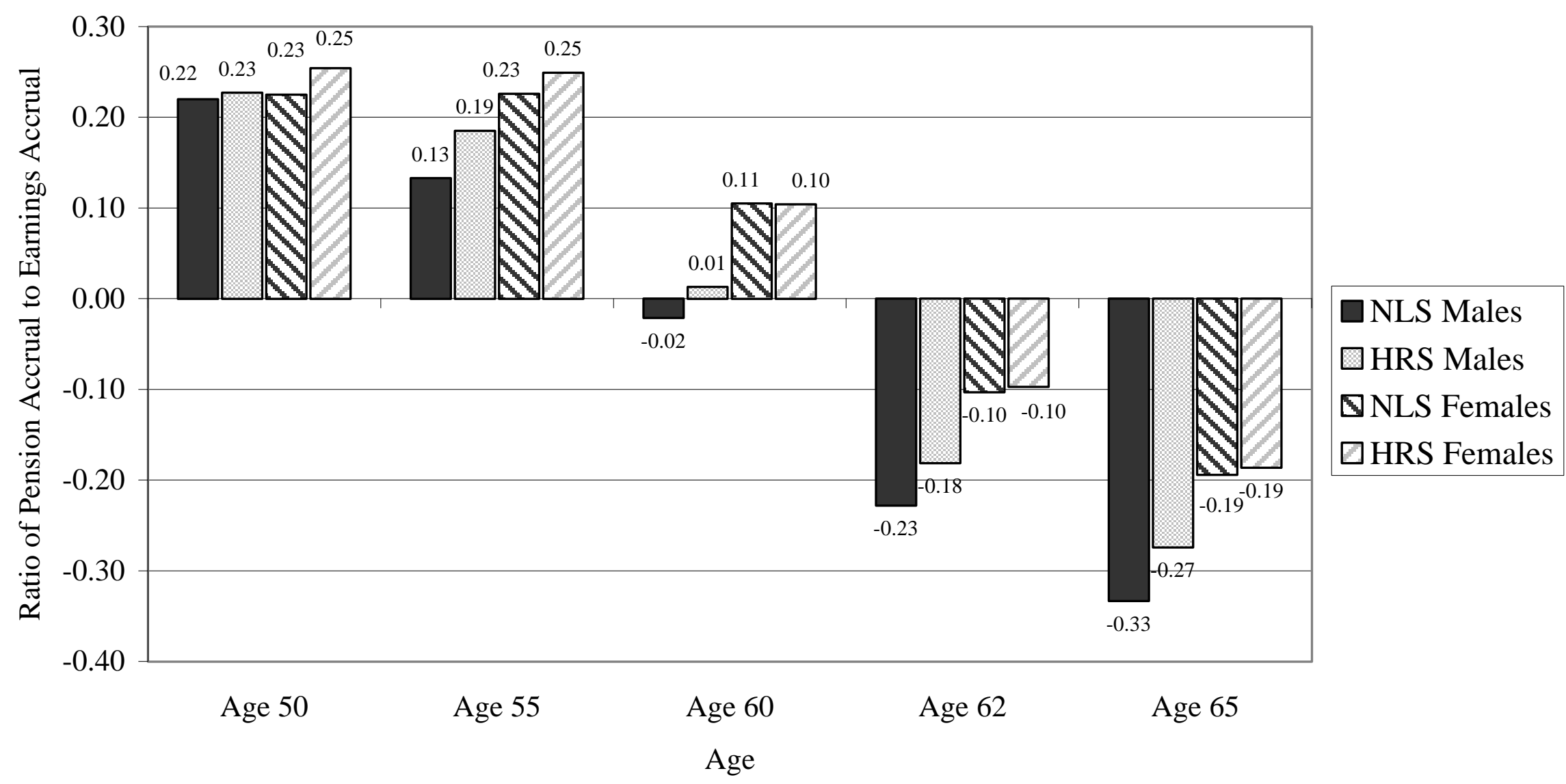


Figure 17: Pension Accrual by Relation to Early and Normal Retirement Age for those with Defined Benefit Plans, by Survey and Gender

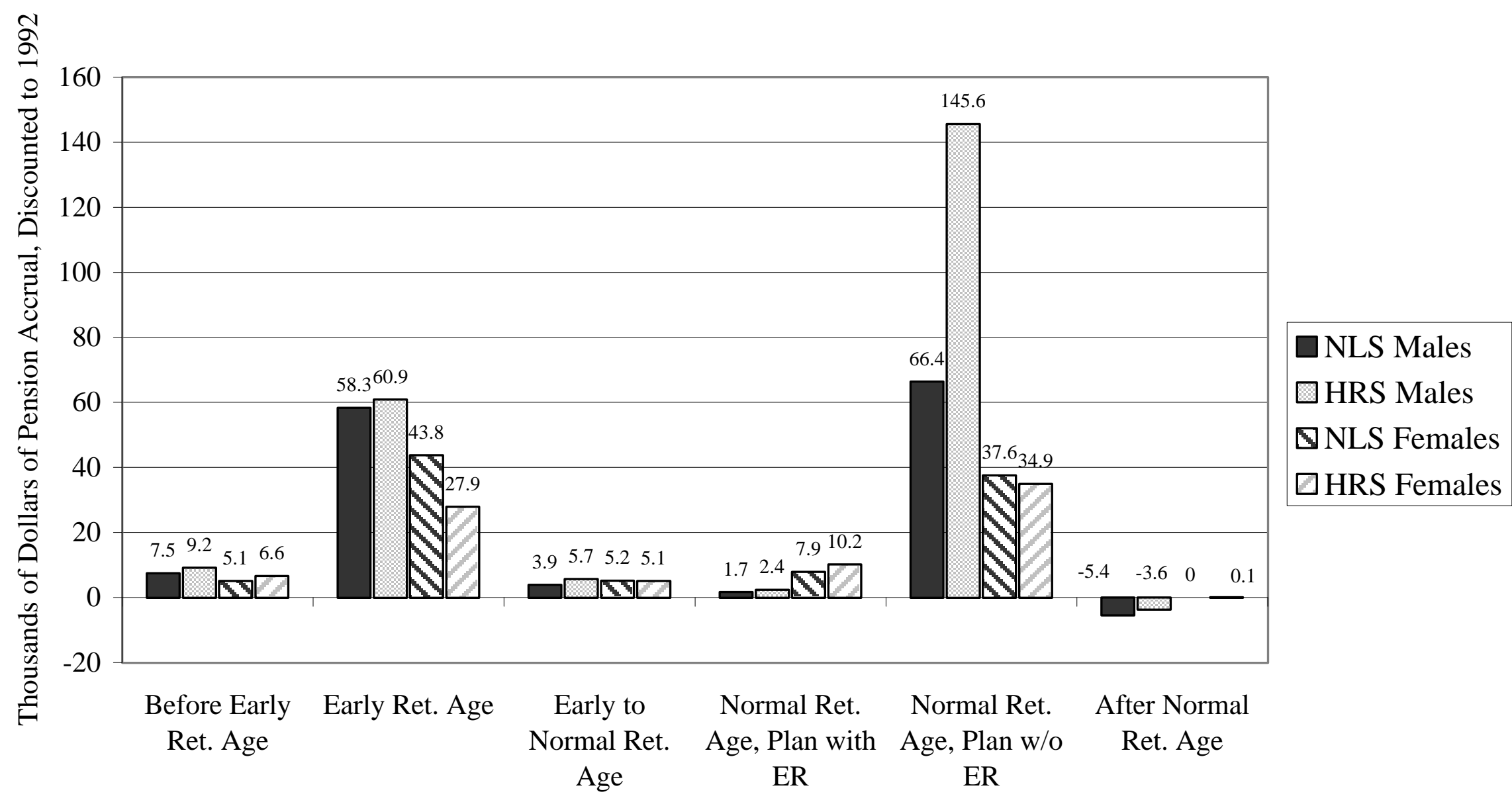


Figure 18: Earnings Accrual for those with Defined Benefit Plans by Relation to Early and Normal Retirement Age

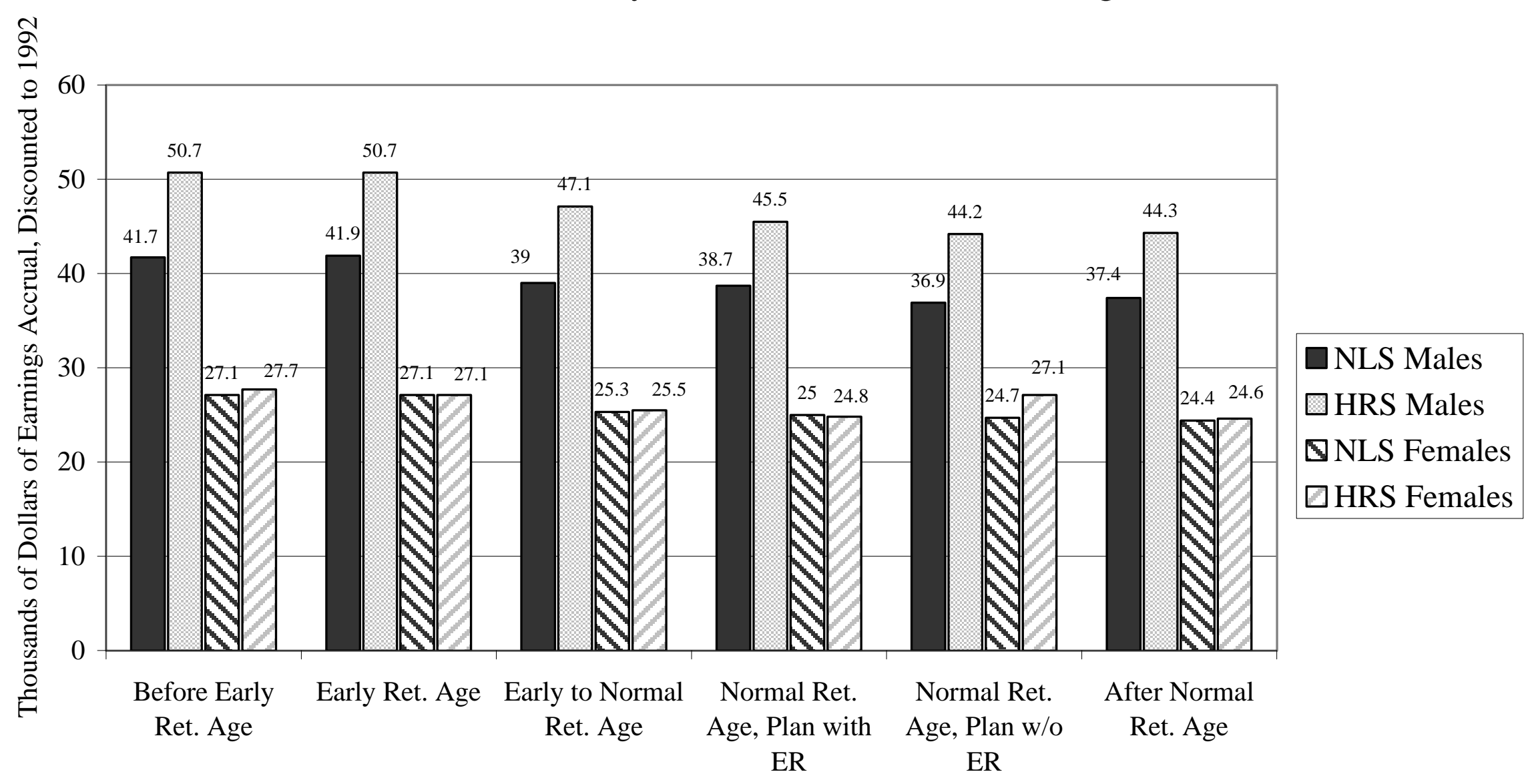


Figure 19: Ratio of Pension Accrual to Earnings Accrual for those with Defined Benefit Plans by Relation to Early and Normal Retirement Age

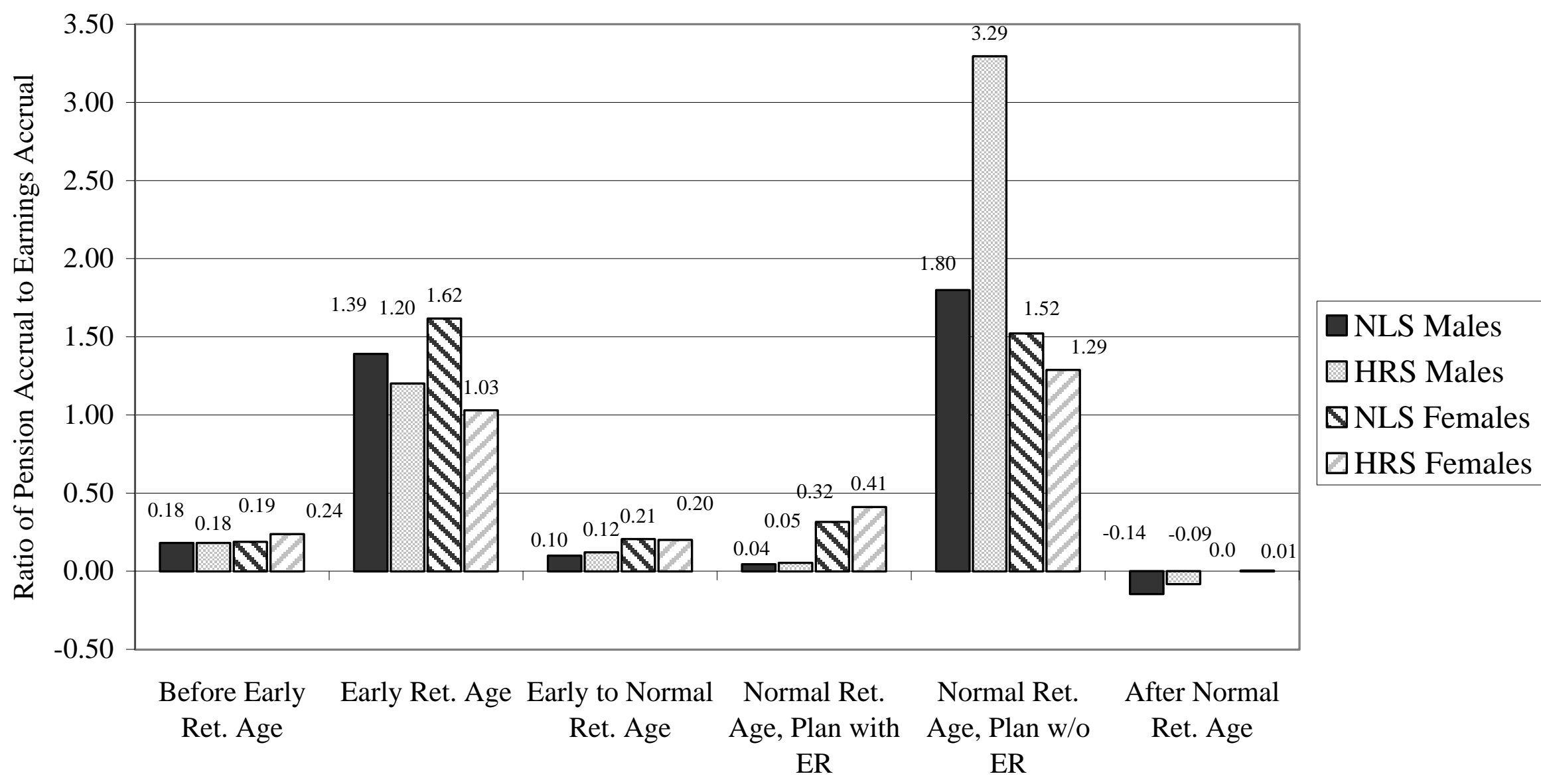


Figure 20: HRS vs. NLS-MW; Percent of Households with a Pension by Earnings Percentile



Earnings Percentile 
Figure 21: HRS vs. NLS-MW; Pension Values by Earnings Percentile for All Households

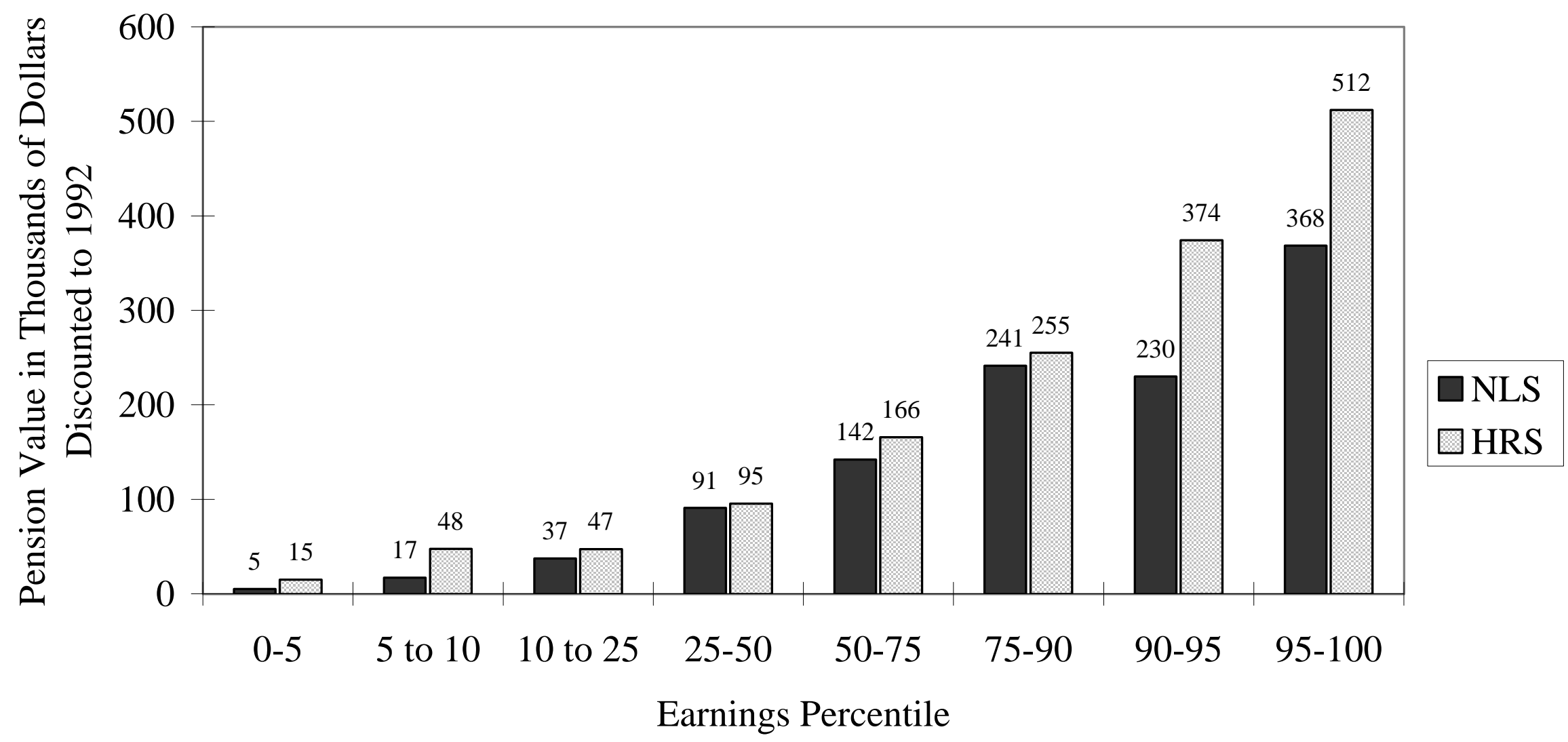


Figure 22: HRS vs. NLS-MW; Pension Values for Pension Covered

Households by Earnings Percentile

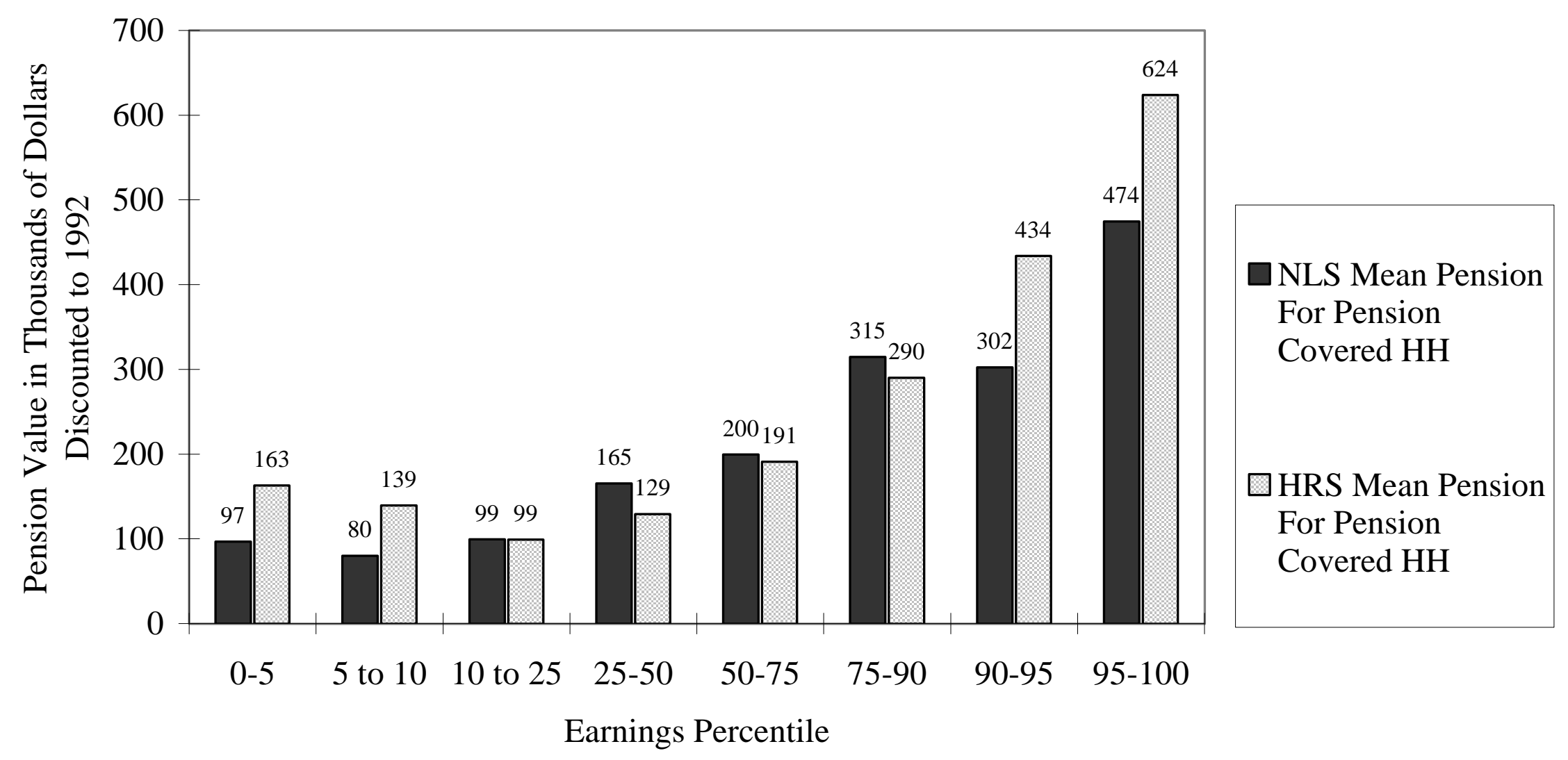


Appendix:

All tables will appear in the appendix. 
Table 1: Number of Observations With Matched Pension Plans Used in the Empirical Analysis

\begin{tabular}{|l|c|c|c|c|}
\hline $\begin{array}{l}\text { Type of Plan Covering } \\
\text { Respondent }\end{array}$ & NLS-MW Males & HRS Males & NLS-MW Females & HRS Females \\
\hline $\begin{array}{l}\text { DB or Combination } \\
\text { Plan }\end{array}$ & 808 & 3279 & 676 & 2374 \\
\hline DC Plan & 144 & 84.3 & 80.8 & 130 \\
\hline $\begin{array}{l}\text { Weighted Share of DB } \\
\text { Plans }\end{array}$ & 952 & 4041 & 83.4 & 673 \\
\hline $\begin{array}{l}\text { Total Respondents with } \\
\text { Pensions }\end{array}$ & $20.6 \%$ & $54.5 \%$ & 306 \\
\hline $\begin{array}{l}\text { Match Rate for Main* } \\
\text { Pensions }\end{array}$ & & & $38.3 \%$ & $56.3 \%$ \\
\hline
\end{tabular}

*The main pension is defined as the pension held at age 50, or the last pension held before age 50 if no pension was held at age 50 , or the first pension held after 50 if there was no pension held before then. 
Table 2 A: Means of Present Values of Defined Benefit Pensions and Accumulated Earnings, By Survey, Gender and Retirement Age

\begin{tabular}{|c|c|c|c|c|c|}
\hline & Age 50 & Age 55 & Age 60 & Age 65 & Age 70 \\
\hline & \multicolumn{5}{|c|}{ Present Value of Defined Benefit Pensions in $(\$ 000)$} \\
\hline NLS Males & 130 & 184 & 222 & 230 & $\overline{210}$ \\
\hline HRS Males & 146 & 214 & 261 & 270 & 257 \\
\hline NLS Females & 64 & 102 & 136 & 153 & 149 \\
\hline \multirow[t]{2}{*}{ HRS Females } & 70 & 114 & 149 & 161 & 158 \\
\hline & \multicolumn{5}{|c|}{ Cumulative Earnings in $(\$ 000)$} \\
\hline NLS Males & 962 & 1171 & 1369 & 1557 & 1735 \\
\hline HRS Males & 1105 & 1353 & 1587 & 1810 & 2021 \\
\hline NLS Females & 432 & 566 & 694 & 815 & 930 \\
\hline \multirow[t]{2}{*}{ HRS Females } & 496 & 633 & 762 & 885 & 1002 \\
\hline & \multicolumn{5}{|c|}{ Pension/Cumulative Earnings } \\
\hline NLS Males & 0.135 & 0.157 & 0.162 & 0.148 & 0.121 \\
\hline HRS Males & 0.132 & 0.158 & 0.164 & 0.149 & 0.127 \\
\hline NLS Females & 0.148 & 0.180 & 0.196 & 0.188 & 0.160 \\
\hline HRS Females & 0.141 & 0.180 & 0.196 & 0.189 & 0.158 \\
\hline
\end{tabular}


Table 2B: Means of Present Values of Defined Benefit Pensions and Accumulated Earnings By Survey, Gender and Retirement Date

\begin{tabular}{|c|c|c|c|}
\hline & 1992 Pension & $\begin{array}{c}\text { Early Retirement } \\
\text { Pension }\end{array}$ & $\begin{array}{c}\text { Normal Retirement } \\
\text { Pension }\end{array}$ \\
\hline & \multicolumn{3}{|c|}{ Present Value of Defined Benefit Pensions in $(\$ 000)$} \\
\hline NLS Males & 201 & 193 & $\overline{230}$ \\
\hline HRS Males & 187 & 209 & 271 \\
\hline NLS Females & 118 & 106 & $\overline{144}$ \\
\hline \multirow[t]{2}{*}{ HRS Females } & 79 & 108 & $\overline{152}$ \\
\hline & \multicolumn{3}{|c|}{ Cumulative Earnings in $(\$ 000)$} \\
\hline NLS Males & 1291 & 1178 & $\overline{1414}$ \\
\hline HRS Males & 1228 & 1243 & 1639 \\
\hline NLS Females & 630 & 552 & 703 \\
\hline \multirow[t]{2}{*}{ HRS Females } & 510 & 602 & 781 \\
\hline & \multicolumn{3}{|c|}{ Pension/Cumulative Earnings } \\
\hline NLS Males & 0.152 & 0.164 & 0.163 \\
\hline HRS Males & 0.143 & 0.168 & 0.165 \\
\hline NLS Females & 0.187 & 0.192 & 0.205 \\
\hline HRS Females & 0.155 & 0.179 & 0.195 \\
\hline
\end{tabular}

These are values that the pension would achieve if the respondent stayed until the indicated age, even if the pension is for a previous job. 
Table 3A: Medians of Present Values of Defined Benefit Pensions and Accumulated Earnings, By Survey, Gender and Retirement Age

\begin{tabular}{|c|c|c|c|c|c|}
\hline & Age 50 & Age 55 & Age 60 & Age 65 & Age 70 \\
\hline & \multicolumn{5}{|c|}{ Present Value of Defined Benefit Pension in $(\$ 000)$} \\
\hline NLS Males & 51 & 123 & 166 & 172 & 157 \\
\hline HRS Males & 76 & 143 & 197 & 210 & 203 \\
\hline NLS Females & 18 & 47 & 93 & 111 & 108 \\
\hline \multirow[t]{2}{*}{ HRS Females } & 33 & 68 & 103 & 119 & 121 \\
\hline & \multicolumn{5}{|c|}{ Cumulative Earnings in $(\$ 000)$} \\
\hline NLS Males & 862 & 1069 & 1258 & 1441 & 1615 \\
\hline HRS Males & 842 & 1043 & 1233 & 1417 & 1599 \\
\hline NLS Females & 308 & 430 & 565 & 680 & 801 \\
\hline \multirow[t]{2}{*}{ HRS Females } & 341 & 465 & 584 & 705 & 807 \\
\hline & \multicolumn{5}{|c|}{ Pension/Cumulative Earnings } \\
\hline NLS Males & 0.059 & 0.115 & 0.132 & 0.119 & 0.097 \\
\hline HRS Males & 0.090 & 0.137 & 0.160 & 0.148 & 0.127 \\
\hline NLS Females & 0.058 & 0.109 & 0.165 & 0.163 & 0.135 \\
\hline HRS Females & 0.097 & 0.146 & 0.176 & 0.169 & 0.150 \\
\hline
\end{tabular}


Table 3B: Medians of Present Values of Defined Benefit Pensions and Accumulated Earnings By Survey, Gender and Retirement Date

\begin{tabular}{|c|c|c|c|}
\hline & 1992 Pension & $\begin{array}{c}\text { Early Retirement } \\
\text { Pension }\end{array}$ & $\begin{array}{c}\text { Normal Retirement } \\
\text { Pension }\end{array}$ \\
\hline & \multicolumn{3}{|c|}{ Present Value of Defined Benefit Pensions in $(\$ 000)$} \\
\hline NLS Males & 142 & 144 & 181 \\
\hline HRS Males & 107 & 143 & 208 \\
\hline NLS Females & 73 & 58 & 104 \\
\hline \multirow[t]{2}{*}{ HRS Females } & 36 & 66 & 108 \\
\hline & \multicolumn{3}{|c|}{ Cumulative Earnings in $(\$ 000)$} \\
\hline NLS Males & 1165 & 1063 & 1267 \\
\hline HRS Males & 932 & 999 & 1268 \\
\hline NLS Females & 498 & 462 & 611 \\
\hline \multirow[t]{2}{*}{ HRS Females } & 345 & 462 & 618 \\
\hline & \multicolumn{3}{|c|}{ Pension/Cumulative Earnings } \\
\hline NLS Males & 0.122 & 0.135 & 0.143 \\
\hline HRS Males & 0.115 & 0.143 & 0.164 \\
\hline NLS Females & 0.147 & 0.126 & 0.170 \\
\hline HRS Females & 0.104 & 0.143 & 0.175 \\
\hline
\end{tabular}


Table 4: Means of Present Values of Defined Contribution Pensions and Accumulated Earnings, By Survey, Gender and Retirement Age

\begin{tabular}{|c|c|c|c|c|c|c|}
\hline & Age 50 & Age 55 & Age 60 & Age 65 & Age 70 & 1992 \\
\hline & \multicolumn{6}{|c|}{ Present Value of Defined Contribution Pensions in $(\$ 000)$} \\
\hline NLS Males & 121 & 141 & 161 & 182 & 201 & 158 \\
\hline HRS Males & 101 & 135 & 168 & 199 & 228 & 116 \\
\hline NLS Females & 41 & 58 & 73 & 88 & 102 & 67 \\
\hline \multirow[t]{2}{*}{ HRS Females } & 42 & 58 & $\overline{72}$ & 85 & 98 & 40 \\
\hline & \multicolumn{6}{|c|}{ Cumulative Earnings in $(\$ 000)$} \\
\hline NLS Males & 933 & 1140 & $\overline{1336}$ & 1522 & 1698 & $\overline{1255}$ \\
\hline HRS Males & 961 & 1230 & 1484 & 1726 & 1955 & 1086 \\
\hline NLS Females & 363 & 485 & 601 & 711 & 815 & 545 \\
\hline \multirow[t]{2}{*}{ HRS Females } & 390 & 513 & 630 & 740 & 845 & 382 \\
\hline & \multicolumn{6}{|c|}{ Pension/Cumulative Earnings } \\
\hline NLS Males & 0.130 & 0.124 & 0.121 & 0.120 & 0.118 & 0.126 \\
\hline HRS Males & 0.105 & 0.110 & 0.113 & 0.115 & 0.117 & 0.107 \\
\hline NLS Females & 0.113 & 0.120 & 0.121 & 0.124 & 0.125 & 0.123 \\
\hline HRS Females & 0.108 & 0.113 & 0.114 & 0.115 & 0.116 & 0.105 \\
\hline
\end{tabular}

These are values that the pension would achieve if the respondent stayed until the indicated age, even if the pension is for a previous job. 
Table 5: Means of Accruals for Defined Benefit Pensions and Accumulated Earnings, By Survey, Gender and Retirement Age

\begin{tabular}{|c|c|c|c|c|c|}
\hline & Age 50 & Age 55 & Age 60 & Age 62 & Age 65 \\
\hline & \multicolumn{5}{|c|}{ Defined Benefit Pension Accrual in (\$000) } \\
\hline NLS Males & 9.4 & 5.4 & -0.8 & -8.3 & -11.5 \\
\hline HRS Males & 11.5 & 8.9 & 0.6 & -7.8 & -11.2 \\
\hline NLS Females & 6.2 & 5.9 & 2.6 & -2.4 & -4.3 \\
\hline \multirow[t]{2}{*}{ HRS Females } & 7.1 & 6.6 & 2.6 & -2.3 & -4.2 \\
\hline & \multicolumn{5}{|c|}{ Earnings Accrual in $(\$ 000)$} \\
\hline NLS Males & 42.7 & 40.5 & 38.4 & 36.4 & 34.5 \\
\hline HRS Males & 50.6 & 48.0 & 45.5 & 43.1 & 40.9 \\
\hline NLS Females & 27.5 & 26.1 & 24.7 & 23.4 & 22.2 \\
\hline \multirow[t]{2}{*}{ HRS Females } & 28.0 & 26.5 & 25.1 & 23.8 & 22.6 \\
\hline & \multicolumn{5}{|c|}{ Pension Accrual/Earnings Accrual } \\
\hline NLS Males & 0.220 & 0.133 & -0.021 & -0.228 & -0.333 \\
\hline HRS Males & 0.227 & 0.185 & 0.013 & -0.181 & -0.274 \\
\hline NLS Females & 0.225 & 0.226 & 0.105 & -0.103 & -0.194 \\
\hline HRS Females & 0.254 & 0.249 & 0.104 & -0.097 & -0.186 \\
\hline
\end{tabular}

These are values that the pension would achieve if the respondent stayed until the indicated age, even if the pension is for a previous job. 
Table 6: Means of Accruals for Defined Benefit Pensions and Accumulated Earnings, By Survey, Gender, Retirement Age and Presence of Early Retirement Benefits

\begin{tabular}{|c|c|c|c|c|c|c|}
\hline & \multirow[b]{2}{*}{$\begin{array}{c}\text { Before Early } \\
\text { Retirement Age }\end{array}$} & \multicolumn{3}{|c|}{ Plans with Early Retirement } & \multirow{2}{*}{$\begin{array}{c}\text { Plans without } \\
\text { Early Retirement }\end{array}$} & \multirow[b]{2}{*}{$\begin{array}{l}\text { After Normal } \\
\text { Retirement Age }\end{array}$} \\
\hline & & $\begin{array}{c}\text { At Early } \\
\text { Retirement Age }\end{array}$ & $\begin{array}{l}\text { Between Early } \\
\text { Retirement Age } \\
\text { and Normal } \\
\text { Retirement Age }\end{array}$ & $\begin{array}{c}\text { At Normal } \\
\text { Retirement Age }\end{array}$ & & \\
\hline NLS Males & 7.5 & 58.3 & 3.9 & 1.7 & 66.4 & -5.4 \\
\hline HRS Males & 9.2 & 60.9 & 5.7 & 2.4 & 145.6 & -3.6 \\
\hline NLS Females & 5.1 & 43.8 & 5.2 & 7.9 & 37.6 & 0 \\
\hline \multirow[t]{2}{*}{ HRS Females } & 6.6 & 27.9 & 5.1 & 10.2 & 34.9 & 0.1 \\
\hline & \multicolumn{6}{|c|}{ Earnings Accrual in $(\$ 000)$} \\
\hline NLS Males & 41.7 & 41.9 & 39.0 & 38.7 & 36.9 & 37.4 \\
\hline NLS Females & 27.1 & 27.1 & 25.3 & 25.0 & 24.7 & 24.4 \\
\hline \multirow[t]{2}{*}{ HRS Females } & 27.7 & 27.1 & 25.5 & 24.8 & 27.1 & 24.6 \\
\hline & \multicolumn{6}{|c|}{ Pension Accrual/Earnings Accrual } \\
\hline NLS Males & 0.180 & 1.391 & 0.100 & 0.044 & 1.799 & -0.144 \\
\hline HRS Males & 0.181 & 1.201 & 0.121 & 0.053 & 3.294 & -0.0815 \\
\hline NLS Females & 0.188 & 1.616 & 0.206 & 0.316 & 1.522 & 0.000 \\
\hline HRS Females & 0.238 & 1.030 & 0.200 & 0.411 & 1.288 & 0.004 \\
\hline
\end{tabular}

These are values that the pension would achieve if the respondent stayed until the indicated age, even if the pension is for a previous job. For males with DB plans in the NLS-MW, there are 808 observations, with 626 in plans offering early retirement (ER) benefits, and 182 with no ER benefits. There are 676 observations for females with DB pensions in the NLS-MW, with 513 in plans offering ER benefits, and 163 in plans without ER benefits. Of the 3279 males with a DB plan in the HRS, 2735 have an ER provision, while 544 do not. Of the 2374 women with pensions in the HRS, 1955 have an ER provision, while 419 do not. 
Table 7: Pension Wealth and Other Characteristics of NLS-MW and HRS Households

\begin{tabular}{|c|c|c|}
\hline & $\begin{array}{l}\text { NLS Mature } \\
\text { Women }\end{array}$ & $\begin{array}{l}\text { Health and } \\
\text { Retirement Study }\end{array}$ \\
\hline \multicolumn{3}{|l|}{ All Households } \\
\hline Percent Married & 64.1 & 68.2 \\
\hline Percent Single Male & 0.0 & 10.1 \\
\hline Percent Single Female & 35.9 & 21.6 \\
\hline Percent With Pensions & 57.7 & 71.1 \\
\hline Mean Pension & 131,120 & 158,131 \\
\hline Mean Pension among Households with Pensions & 227,199 & 222,272 \\
\hline Percent of Households with Pensions on Current Job & 24.3 & 48 \\
\hline Mean Pension on Current Job & 41,802 & 89,830 \\
\hline $\begin{array}{l}\text { Mean Pension on Current Job among Households with Pensions } \\
\text { on Current Job }\end{array}$ & 172,016 & 187,744 \\
\hline Percent of Households with Pensions on Previous Job & 38.9 & 35.6 \\
\hline Mean Pension on Previous Jobs & 89,318 & 68,301 \\
\hline $\begin{array}{l}\text { Mean Pension on Previous Jobs among Households with } \\
\text { Pensions on Previous Job }\end{array}$ & 229,329 & 192,050 \\
\hline \multicolumn{3}{|l|}{ Married Households } \\
\hline Percent With Pensions & 69.0 & 79.7 \\
\hline Mean Pension & 178,268 & 199,014 \\
\hline Mean Pension among Households with Pensions & 258,358 & 249,859 \\
\hline Percent of Households with Pensions on Current Job & 27.5 & 53.9 \\
\hline Mean Pension on Current Job & 53,389 & 110,708 \\
\hline $\begin{array}{l}\text { Mean Pension on Current Job among Households with Pensions } \\
\text { on Current Job }\end{array}$ & 194,387 & 205,559 \\
\hline Percent of Households with Pension on Previous Job & 49.6 & 42.5 \\
\hline Mean Pension on Previous Jobs & 124,879 & 88,306 \\
\hline $\begin{array}{l}\text { Mean Pension on Previous Jobs among Households with } \\
\text { Pensions }\end{array}$ & 251,878 & 208,022 \\
\hline
\end{tabular}




\begin{tabular}{|c|c|c|}
\hline & $\begin{array}{l}\text { NLS Mature } \\
\text { Women }\end{array}$ & $\begin{array}{l}\text { Health and } \\
\text { Retirement Study }\end{array}$ \\
\hline \multicolumn{3}{|l|}{ Single Females } \\
\hline Percent with Pensions & 37.6 & 46.3 \\
\hline Mean Pension & 46,984 & 43,762 \\
\hline Mean Pension among Households with Pensions & 125,029 & 94,558 \\
\hline Percent of Households with Pensions on Current Job & 18.7 & 34.0 \\
\hline Mean Pension on Current Job & 21,138 & 32,750 \\
\hline Mean Pension on Current Job among Households with Pensions & 113,289 & 96,201 \\
\hline Percent of Households with Pensions on Previous Jobs & 20.0 & 14.3 \\
\hline Mean Pension on Previous Jobs & 25,846 & 11,012 \\
\hline $\begin{array}{l}\text { Mean Pension on Previous Jobs among Households with } \\
\text { Pensions }\end{array}$ & 129,315 & 78,415 \\
\hline \multicolumn{3}{|l|}{ Single Males } \\
\hline Percent With Pensions & & 56.5 \\
\hline Mean Pension & & 99,869 \\
\hline Mean Pension among Households with Pensions & & 176,861 \\
\hline Percent of Households with Pensions on Current Job & & 36 \\
\hline Mean Pension on Current Job & & 78,007 \\
\hline $\begin{array}{l}\text { Mean Pension on Current Job among Households with Pensions } \\
\text { on Current Job }\end{array}$ & & 187,595 \\
\hline Percent of Households with Pensions on Previous Job & & 23 \\
\hline Mean Pension on Previous Jobs & & 31,862 \\
\hline $\begin{array}{l}\text { Mean Pension on Previous Jobs among Households with } \\
\text { Pensions on Previous Jobs }\end{array}$ & & 138,032 \\
\hline
\end{tabular}

